\title{
Ascl2 activation by YAP1/KLF5 ensures the self-renewability of colon cancer progenitor cells
}

\author{
Xiaolong Wei ${ }^{1}$, Jun Ye ${ }^{1}$, Yangyang Shang ${ }^{1}$, Haoyuan Chen ${ }^{1}$, Shanxi Liu ${ }^{1}$, Li Liu ${ }^{1}$ and \\ Rongquan Wang ${ }^{1}$ \\ ${ }^{1}$ Institute of Gastroenterology of PLA, Southwest Hospital, Third Military Medical University, Chongqing, China \\ Correspondence to: Rongquan Wang, email: rongquanw@hotmail.com \\ Keywords: achaete scute-like 2; Wnt signaling; Hippo signaling; colorectal cancer; progenitor cells
}

Received: June 21, $2017 \quad$ Accepted: November 08, $2017 \quad$ Published: November 27, 2017

Copyright: Wei et al. This is an open-access article distributed under the terms of the Creative Commons Attribution License 3.0 (CC BY 3.0), which permits unrestricted use, distribution, and reproduction in any medium, provided the original author and source are credited.

\section{ABSTRACT}

Achaete scute-like 2 (Ascl2) is the Wnt signaling target, its regulation by other signaling is undefined. Now we demonstrated that $\mathrm{CD} 133^{+} / \mathrm{CD}^{+} 4^{+}$cell population from HT-29 or Caco-2 cells exhibited cancer stem cell (CSC) properties with highly expressed Ascl2, which is related to the Hippo signaling pathway. YAP1 interference in $\mathrm{CD}_{133^{+}} / \mathrm{CD}_{4} 4^{+} \mathrm{HT}-29$ or Caco-2 cells reduced their proliferation, colony-forming ability and tumorsphere formation in vitro and inhibited the 'stemness'-associated genes and Ascl 2 expression. Enforcing YAP1 expression in HT-29 or Caco-2 cells triggered the opposite changes. Ascl2 interference reversed the phenotype of YAP1enforced expressed HT-29 or Caco-2 cells. Krüppel-like factor 5 (KLF5) protein, not KLF5 mRNA levels, were increased due to YAP1 overexpression which is reported to prevent KLF5 degradation. Co-immunoprecipitation (Co-IP) assays demonstrated that YAP1 bound with KLF5 in HT-29 and Caco-2 cells. Luciferase and chromatin immunoprecipitation (ChIP) assays indicated that both YAP1 and KLF5 bound to the first two loci with GC-boxes in Ascl 2 promoter and induced Ascl2 transcription. The decreased Ascl 2 transcription by YAP1 interference required an intact KLF5 binding site (GC-box) within Ascl2 promoter, KLF5 knockdown reduced YAP1 binding and Ascl2 luciferase reporter activity upon YAP1 overexpression. Positive correlation among YAP1 and Ascl2 mRNA levels was observed in colorectal cancer (CRC) samples. Thus, our study demonstrated that Ascl2, a fate decider of CRC progenitor cells can be activated by the Hippo signaling pathway in CRC progenitor cells, and ensured their self-renewability.

\section{INTRODUCTION}

Colorectal cancer (CRC) is a leading cause of morbidity and mortality in developed countries [1]. Cancer stem cells (CSCs), which exhibit stem-like features, sustain tumor formation, cause metastasis, and are resistant to therapy, have been proposed to explain the functional heterogeneity and carcinogenesis [2-5]. Protein-coding genes and their products participate in the 'stemness' maintenance and tumorigenicity of CRC progenitor cells [6-8]. Thus, it is pivotal to identify the signaling pathways involved in CRC progenitor cells to develop novel reagents that target the refractory CRC progenitor cell population [9].

Achaete scute-like 2 (Ascl2/Mash2/Hash2), a helixloop-helix transcription factor and downstream target of Wnt signaling, plays a critical role in intestinal Lgr5 ${ }^{+}$ cryptic stem cells and CRC progenitor cells $[10,11]$. Ascl2 is abundantly expressed in colorectal cancer; has the potential to shift the hierarchy of stem and progenitor cells during liver metastasis, resulting in self-renewal rather than differentiation; and potentially affects the clinical behavior of these tumors [12-14]. Ascl2 can also initiate T-helper cell development, trophoblast progenitor 
differentiation of mouse trophoblast stem cells, and differentiation of intestinal neoplastic epithelial cells that results in a goblet cell phenotype [15-17]. Mash2 in trophoblast stem cells can be transcriptionally increased by Tssc3, HIF-1 $\alpha$, HIF-2 $\alpha$ and OVO-like 1 (OVOL1), and Mash2 expression is decreased due to a Mst1/2 double knockout during mouse placental development [16, 18-20]. In CRC, Ascl2 is significantly induced by either the chemokine receptor CXCR4 or KIAA1199, hypoxia-induced HIF-1 $\alpha$ [21-23]. However, the molecular mechanism of Ascl2 overexpression in CRC progenitor cells is still unclear.

The mammalian Hippo signaling pathway, short for MST1/2-LATS1/2-YAP1/TAZ-TEAD1-4, is a critical pathway involved in determining cell growth rate and organ size [24-26]. MST1 and MST2 (MST1/2) phosphorylate LATS1/2 and Mob1, leading to their activation; LATS1/2 phosphorylates YAP1/TAZ, which causes a cytoplasmic accumulation of the phosphorylated YAP1/TAZ and sequesters its oncogenic function [2729]. The unphosphorylated YAP1/TAZ translocates to the nucleus and binds with TEAD1-4 (TEA domain DNAbinding transcription factors 1-4) and other transcription factors, inducing transcriptional activity that causes cell proliferation and differentiation. YAP1/TAZ activation is widespread in many human tumors and has been shown to be essential for cancer initiation, progression, and metastasis, they function as transcriptional co-activators that shuttle between the cytoplasm and the nucleus, where they induce expression of cell-proliferative and antiapoptotic genes via interactions with transcription factors [30-32].

In 2010, crosstalk study between Wnt and Hippo signaling has been suggested, and evidence of cytoplasmic TAZ inhibiting canonical Wnt signaling has been provided, highlighting that the Hippo pathway can control other signaling cascades [33]. The $\beta$-catenin-YAP1TBX5 (transcription factor) complex is essential to the transformation and survival of $\beta$-catenin-driven cancers [34]. These two pathways are known to be important for epithelial development and homeostasis, and there is accumulating evidence that the Hippo cascade engages in crosstalk with Wnt signaling in epithelial tissues [3537]. Essential crosstalk between Hippo and Wnt occurs during epithelial transcriptional control. YAP1 reprograms Lgr $5^{+}$cryptic stem cells by inhibiting the Wnt homeostatic program while inducing a regenerative program that includes the activation of EGFR signaling, which drives cancer initiation [38]. However, understanding the molecular mechanisms connecting these signals will require further investigation.

Here, we provided a study that YAP1 combined with KLF5, further bound to the Ascl2 promoter, and then transcriptionally activated Ascl2 expression. This mechanism had an impact on the self-renewability of colon cancer progenitor cells. A correlation between YAP1 and Ascl 2 was present not only in the $\mathrm{CD} 133^{+} \mathrm{CD} 44^{+} \mathrm{CRC}$ cell population but also in colon cancer tissue samples. Ascl2 regulation by YAP1 provided evidence that this Wnt target gene can also be transcriptionally activated by YAP1, an effector of Hippo signaling in CRC progenitor cells, and YAP1-activated Ascl2 expression in CRC progenitor cells controlled their cell state stability and conferred their ability to self-renewability.

\section{RESULTS}

\section{$\mathrm{CD} 133^{+} \mathrm{CD}^{+} 4^{+} \mathrm{HT}-29$ or Caco-2 cells had higher abilities to proliferate and form colonies and tumorspheres}

Fluorescence-activated cell sorting and flow cytometry was used to separate HT-29 and Caco-2

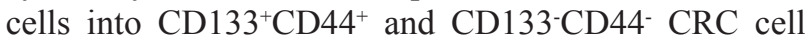
population (Figure $1 \mathrm{~A}$ and $1 \mathrm{~B}$ ). The proliferation rates of the $\mathrm{CD} 133^{+} \mathrm{CD} 44^{+} \mathrm{HT}-29$ or Caco- 2 cells from days 3 to 4 after seeding were significantly higher than CD133CD44- HT-29 or Caco-2 cells (Figure 1C and 1D). More colonies were formed in the $\mathrm{CD} 133^{+} \mathrm{CD} 44^{+} \mathrm{HT}-29$ or Caco-2 cells than CD133-CD44- HT-29 or Caco-2 cells, as determined by the colony formation assay (Figure 1E). Larger tumorspheres were formed in the CD $133^{+} \mathrm{CD} 44^{+}$ HT-29 (Figure 1F) or Caco-2 (Figure 1G) cells, and the cell numbers per tumorsphere in the $\mathrm{CD} 133^{+} \mathrm{CD} 44^{+} \mathrm{HT}-$ 29 or Caco- 2 cells were significantly higher than CD133 CD44- HT-29 or Caco-2 cells (Figure 1H). The results indicated that the $\mathrm{CD} 133^{+} \mathrm{CD} 44^{+} \mathrm{CRC}$ cell population represented colon cancer progenitor cells.

\section{Expression of Ascl2, KLF5, Hippo signaling and 'stemness'-associated genes in $\mathrm{CD} 133^{+} \mathrm{CD}^{+} 4^{+}$and CD133-CD44- CRC cells}

There were higher mRNA levels of 'stemness'associated genes (CD133, CD44, Bmil, C-myc and Oct4), Asc12, KLF5 and YAP1, and lower MST1 level in CD $133{ }^{+} \mathrm{CD}_{4}{ }^{+}$HT-29 and Caco-2 cells compared with CD133-CD44- HT-29 and Caco-2 cells (Figure 2A and 2B). The protein levels of Ascl2, KLF5 and 'stemness'associated genes in $\mathrm{CD} 133^{+} \mathrm{CD}_{4} 4^{+} \mathrm{HT}-29$ and Caco-2 cells were higher than CD133-CD44- HT-29 and Caco2 cells (Figure 2C). The YAP1 protein levels in both the cytoplasm and the nucleus of $\mathrm{CD} 133^{+} \mathrm{CD} 44^{+} \mathrm{HT}-29$ and Caco- 2 cells were higher than CD133-CD44- HT-29 and Caco-2 cells, whereas MST1 and phosphorylated YAP1 were present predominantly in the cytoplasm of CD133-CD44- HT-29 and Caco-2 cells (Figure 2D). The data indicated that an accordant increase of 'stemness'associated genes, Ascl2, KLF5, and YAP1 expression in $\mathrm{CD}_{133}{ }^{+} \mathrm{CD} 44^{+}$HT-29 and Caco- 2 cells. MST1 and phosphorylated YAP1 were higher in the cytoplasm of 
CD133-CD44- HT-29 and Caco-2 cells than $\mathrm{CD}^{-} 133^{+} \mathrm{CD} 44^{+}$ HT-29 and Caco-2 cells (Figure 2D).

\section{Proliferation, $\mathrm{CD} 133^{+} \mathrm{CD}^{+} 4^{+}$percentages, and} Ascl2, KLF5 and 'stemness'-associated genes expressions in YAP1 interfered colon cancer cells

The results from screening for the most efficient siRNA sequence to target YAP1 were shown in Figure 3A, siRNA-YAP1-1 exerted the most efficient YAP1 interference in both $\mathrm{CD} 133^{+} \mathrm{CD} 44^{+}$and $\mathrm{CD} 1333^{-\mathrm{CD}} 44$ CRC cells, and it was then used in further experiments. The proliferation rates of $\mathrm{CD} 133^{+} \mathrm{CD} 44^{+}$and $\mathrm{CD} 133$ CD44- CRC cells from HT-29 (Figure 3B) or Caco2 (Figure 3C) cells from days 1 to 4 after transfected with siRNA-YAP1-1 were based on MTT assays. The proliferation rates of YAP1 interfered $\mathrm{CD} 133^{+} \mathrm{CD} 44^{+} \mathrm{CRC}$ cells were significantly decreased from days 3 to 4 $(P<0.01)$, whereas, the proliferation rates of YAP1 interfered CD133-CD44- CRC cells significantly decreased

A
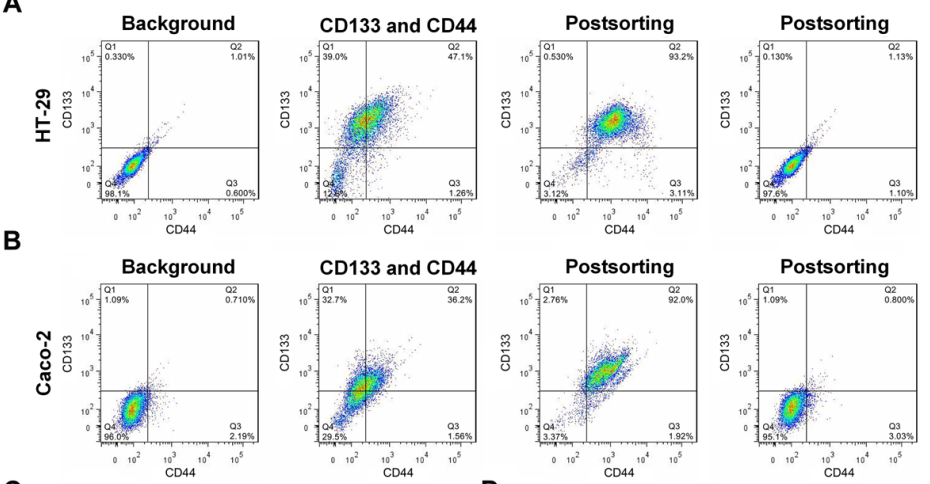

C
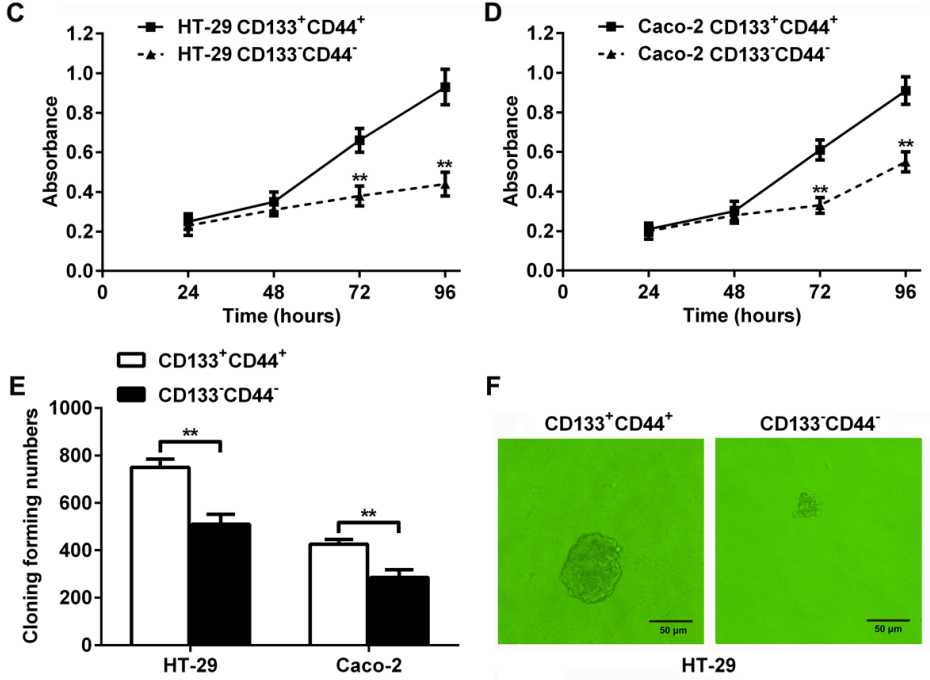

$\mathbf{F}$
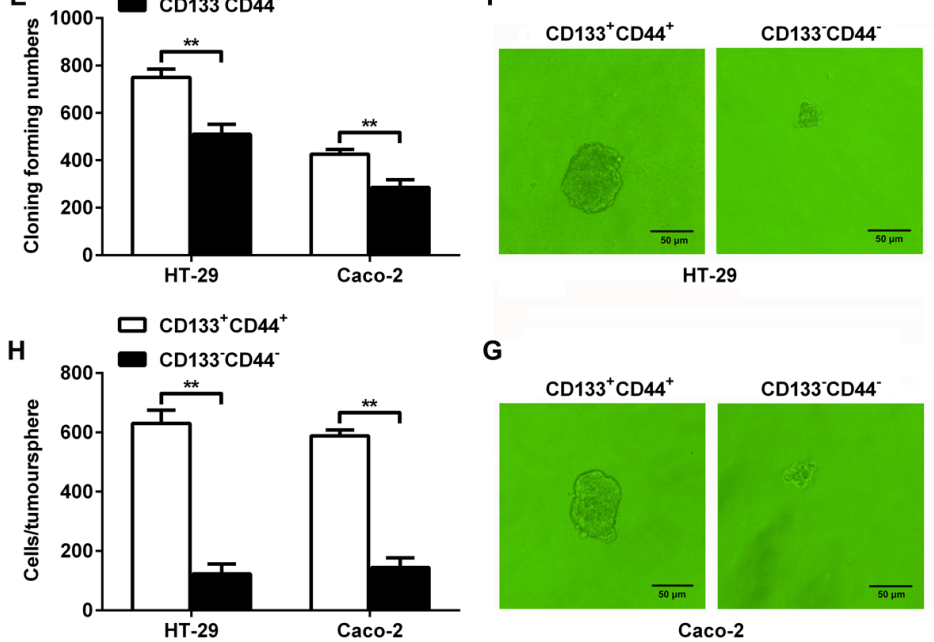

Figure 1: Characterization of $\mathrm{CD}^{-133^{+}} \mathrm{CD}^{+} 4^{+}$and CD133-CD44- CRC cells. (A and B) Fluorescence-activated cell sorting and flow cytometry. CRC cells HT-29 (A) and Caco-2 (B) were separated into CD133 ${ }^{+} \mathrm{CD}_{4} 4^{+}$and CD133-CD44- CRC cell population. (C and D) The proliferation rates of $\mathrm{CD} 133^{+} \mathrm{CD} 44^{+}$and $\mathrm{CD} 133^{-\mathrm{CD}} 44^{-} \mathrm{HT}-29$ (C) or Caco-2 (D) cells from days 1 through 4 after seeding $\left(^{* *}: P<0.01\right)$. (E) The colony formation assay indicated that more colonies were formed in the $\mathrm{CD} 133^{+} \mathrm{CD} 44^{+} \mathrm{CRC}$ cell population than in the CD133-CD44- CRC cell population $\left(^{* *}: P<0.01\right)$. (F and G) Tumorsphere formation of CD133 ${ }^{+} \mathrm{CD} 44^{+}$or CD133-CD44- CRC cell

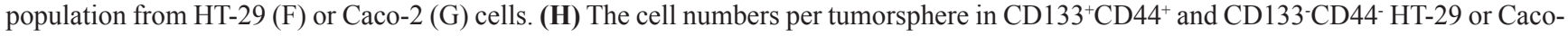
2 cells $\left({ }^{* *}: P<0.01\right)$. 
at day $4(P<0.01)$, and decreased at day 3 only in YAP1 interfered CD133-CD44- HT-29 cells $(P<0.05)$. Only $66.8 \%$ and $55.3 \%$ were CD133 and CD44 positive in YAP1 interfered CD133 ${ }^{+} \mathrm{CD} 44^{+}$HT-29 (Figure 3D) and Caco-2 (Figure 3E) cells compared with $83.6 \%$ and $83.2 \%$ being CD133 and CD44 positive in mock CD133 ${ }^{+} \mathrm{CD} 44^{+}$ CRC cells, respectively. The $\mathrm{CD} 133^{+} \mathrm{CD} 44^{+}$percentages were unaltered despite YAP1 interference in CD133-CD44CRC cells (Figures 3D and 3E). YAP1 knockdown in $\mathrm{CD} 133{ }^{+} \mathrm{CD} 44^{+} \mathrm{CRC}$ cells led to the reduction of KLF5, Ascl2 and 'stemness'-associated genes expression and inhibited the accumulation of YAP1 in the nucleus (Figure $3 \mathrm{~F})$. The protein expression levels of KLF5, Ascl2 and 'stemness'-associated genes in CD133-CD44- HT-29 and Caco- 2 cells were significantly lower than $\mathrm{CD} 133^{+} \mathrm{CD} 44^{+}$ HT-29 and Caco-2 cells (Figure 2C) and not altered despite YAP1 interference using siRNA-YAP1-1 in CD133CD44- HT-29 and Caco-2 cells (data not shown). The data provided evidence that YAP1 is exclusively essential for maintaining the 'stemness' of CD $133^{+} \mathrm{CD} 44^{+} \mathrm{HT}-29$ and Caco- 2 cells, including their proliferation, $\mathrm{CD} 133^{+} \mathrm{CD} 44^{+}$ percentages, and 'stemness'-associated genes expression.
However, it was still unknown whether YAP1 knockdown inhibited the 'stemness' of $\mathrm{CD} 133^{+} \mathrm{CD} 44^{+} \mathrm{HT}-29$ and Caco-2 cells via KLF5-dependent Ascl2 inhibition.

\section{YAP1-enforced expression in HT-29 and Caco- 2 cells increased their proliferation, colony formation, the percentages of $\mathrm{CD} 133^{+} \mathrm{CD} 44^{+}$ population, and tumorsphere formation}

To further determine whether YAP1 could ensure the self-renewability of colon cancer progenitor cells, we established YAP1-enforced HT-29 (lv-YAP1/HT-29) and Caco-2 (lv-YAP1/Caco-2) cell lines with lentivirus particles using an LV5 (EF-1aF/GFP \& Puro) vector with a YAP1 insert. YAP1 relative $\mathrm{mRNA}$ and protein levels in lv-YAP1/HT-29 and lv-YAP1/Caco-2 cells were significantly increased compared with their respective controls (Figures 4A and 4B). The proliferation rates of lv-YAP1/HT-29 and lv-YAP1/Caco-2 cells from days 3 through 4 after seeding were significantly increased than their respective control cells (Figures 4C and 4D). More colonies were formed in lv-YAP1/HT-29 and lv-
A
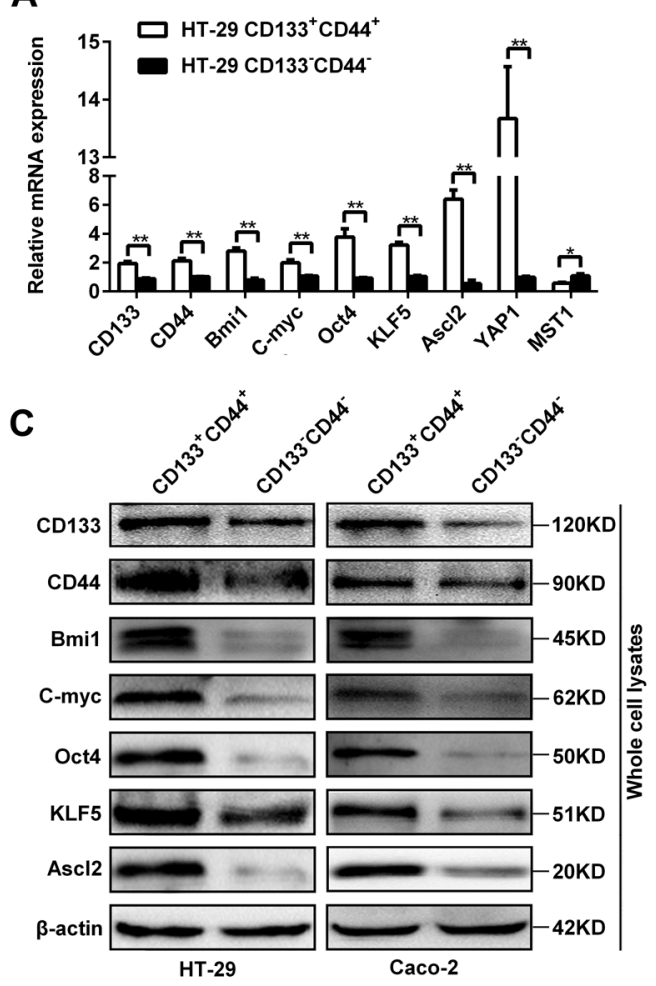

B
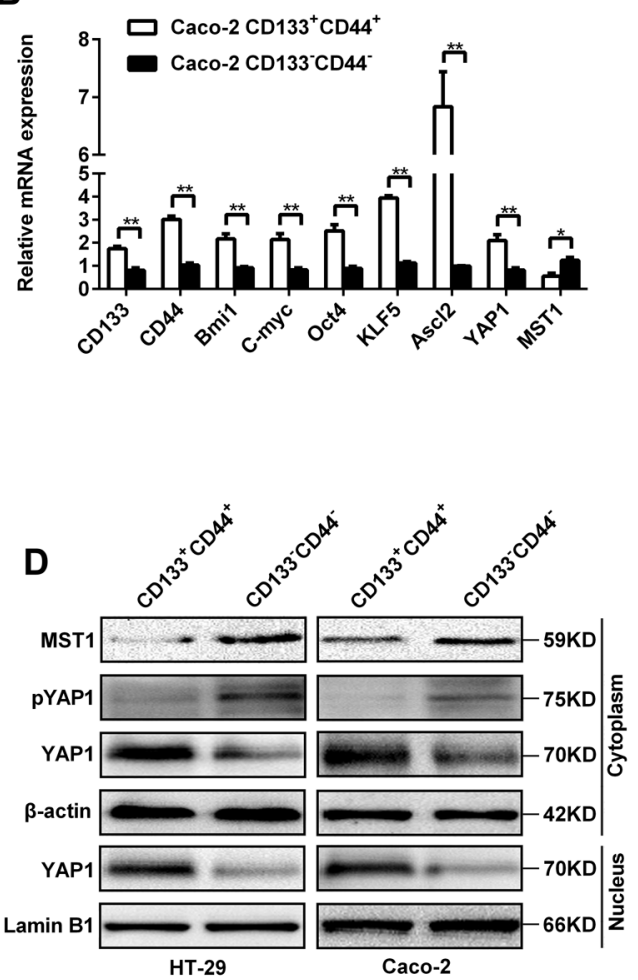

Figure 2: Expression of Ascl2, KLF5, the Hippo signaling pathway, and 'stemness'-associated genes in CD133 ${ }^{+}$CD44 $^{+}$ or CD133-CD44- CRC cells. (A and B) Relative mRNA expression levels of Asc12, KLF5, the Hippo signaling pathway, and 'stemness'associated genes in $\mathrm{CD}_{133}{ }^{+} \mathrm{CD} 44^{+}$or CD133-CD44- HT-29 (A) and Caco-2 (B) cells $\left({ }^{*}: P<0.05,{ }^{* *}: P<0.01\right)$. (C) The protein expression levels of Ascl2, KLF5 and 'stemness'-associated genes in CD133 ${ }^{+} \mathrm{CD} 44^{+}$and CD133-CD44- HT-29 or Caco-2 cells; $\beta$-actin was used as a loading control. (D) The protein expression levels from the Hippo signaling pathway: MST1, phosphorylated YAP1 and YAP1 in the cytoplasm or the nucleus of $\mathrm{CD} 133^{+} \mathrm{CD}_{4} 4^{+}$and $\mathrm{CD} 133^{-} \mathrm{CD} 44^{-} \mathrm{HT}-29$ or Caco-2 cells; $\beta$-actin was used as a loading control for cytoplasmic proteins, and Lamin B1 was used as a loading control for nucleus proteins. 
YAP1/Caco-2 cells than their respective control cells (Figure 4E). In YAP1-enforced HT-29 or Caco-2 cells, $65.5 \%$ and $73.3 \%$ of the population were $\mathrm{CD} 133^{+} \mathrm{CD} 44^{+}$ when compared with $53.1 \%$ and $50.2 \%$ of their control cell population being $\mathrm{CD}_{133}{ }^{+} \mathrm{CD}_{4} 4^{+}$(Figure $4 \mathrm{~F}$ ). Larger tumorspheres were formed in lv-YAP1/HT-29 and lvYAP1/Caco-2 cells compared with their respective control cells, and the cell numbers per tumorsphere in lv-YAP1/ HT-29 and lv-YAP1/Caco-2 cells were significantly higher than their respective control cells (Figure $4 \mathrm{G}$ and $4 \mathrm{H}$ ).
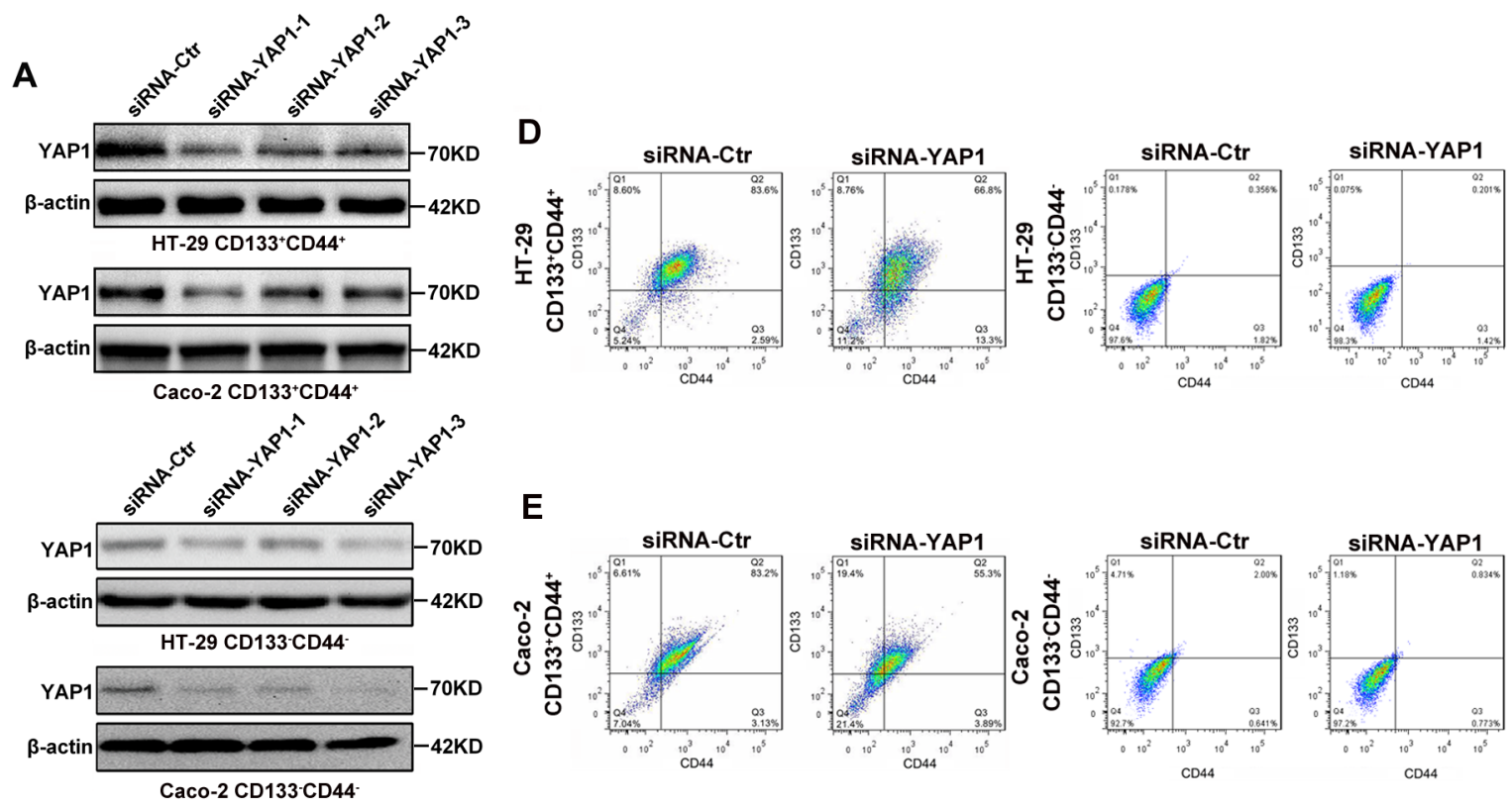

B
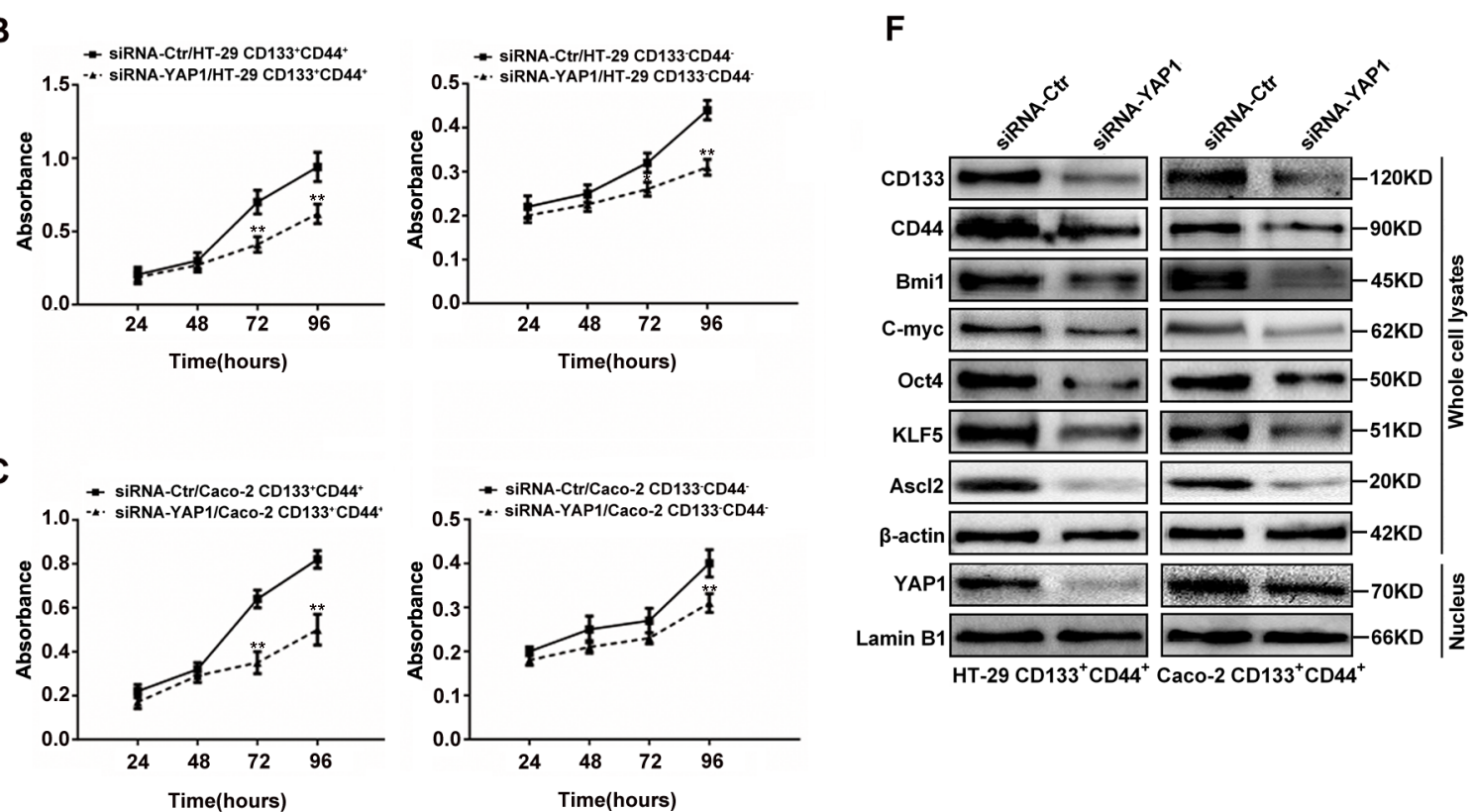

Figure 3: YAP1 knockdown in $\mathrm{CD} 133^{+} \mathrm{CD}^{4} 4^{+}$or $\mathrm{CD} 133-\mathrm{CD} 44^{-} \mathrm{CRC}$ cells affected their proliferation, $\mathrm{CD}^{-} 3^{+} \mathrm{CD} 44^{+}$ percentages, relative gene expression. (A) Western blots of YAP1 in CD133 ${ }^{+} \mathrm{CD} 44^{+}$or $\mathrm{CD} 133^{-} \mathrm{CD} 44^{-} \mathrm{CRC}$ cells transiently transfected with YAP1 siRNA1 (siRNA-YAP1-1), siRNA2 (siRNA-YAP1-2) or siRNA3 (siRNA-YAP1-3); $\beta$-actin was used as a loading control. (B and $\mathrm{C}$ ) The proliferation rates of $\mathrm{CD} 133^{+} \mathrm{CD} 44^{+}$and $\mathrm{CD} 1333^{-\mathrm{CD}} 44^{-} \mathrm{HT}-29$ (B) or Caco-2 (C) cells transfected with siRNA-YAP1-1 from days 1 through 4 after seeding $\left(^{* *}: P<0.01\right)$. (D and E) The $\mathrm{CD} 133^{+} \mathrm{CD} 44^{+}$percentages determined by flow cytometry in YAP1-interfered $\mathrm{CD} 133^{+} \mathrm{CD} 44^{+}$or CD133-CD44- CRC cells. (F) The protein expression levels of Asc12, KLF5 and 'stemness'-associated genes in the whole cell lysates of CD133 ${ }^{+} \mathrm{CD} 44^{+} \mathrm{CRC}$ cells transfected with siRNA-YAP1-1; $\beta$-actin was used as a loading control. YAP1 nuclear accumulation was inhibited in siRNA-YAP1-1-transfected CD133 ${ }^{+} \mathrm{CD} 44^{+}$CRC cells; Lamin B1 was used as an internal control for the nuclear fraction. 
YAP1-enforced expression in HT-29 and Caco-2 cells increased Ascl2, KLF5 and 'stemness'associated genes expression which were reversed by Ascl2 knockdown

To confirm whether the YAP1-enhanced selfrenewability of colon cancer progenitor cells was related to a KLF5-dependent Ascl2 increase, the relative 'stemness'- associated genes expression (mRNA) levels and protein levels in lv-YAP1/HT-29 and lv-YAP1/Caco-2 cells were determined, and they were found to be significantly increased compared to their respective control cells (Figure 5). The KLF5 mRNA levels were unaltered, but its protein levels were increased, and it is reported that KLF5 degradation could be prevented by increased YAP1 expression [39-40]. Ascl2 mRNA and protein expression

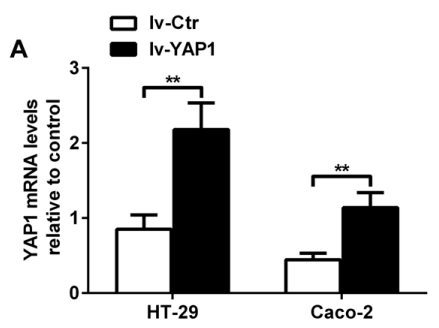

B

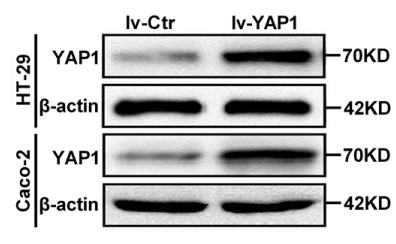

\section{C}
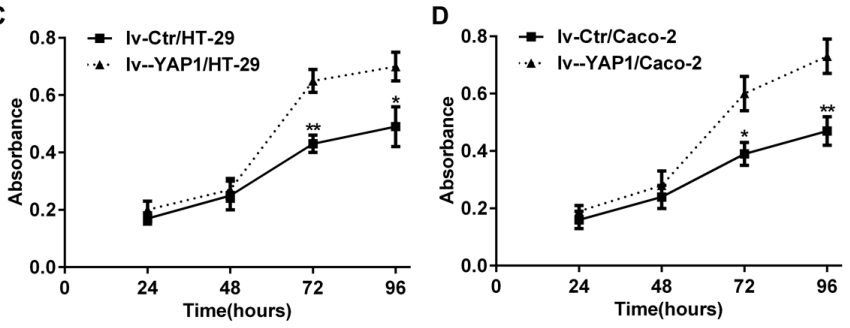

E

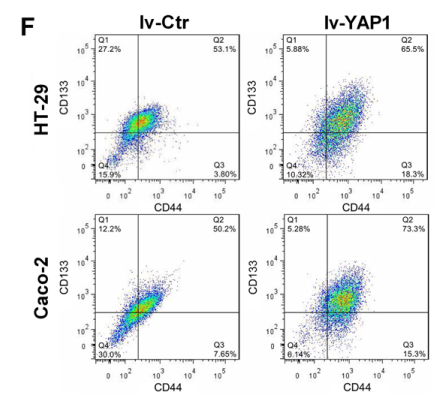

G
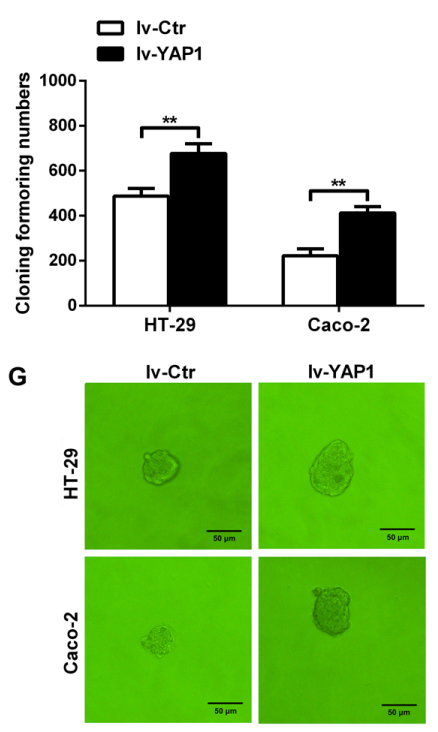

H

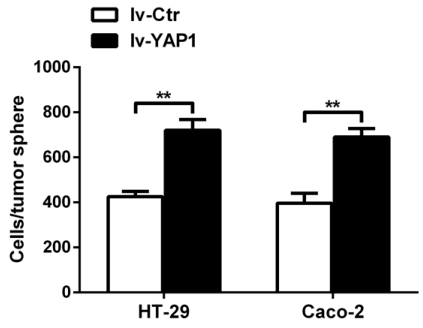

Figure 4: YAP1-enforced expression in HT-29 and Caco-2 cells increased their proliferation, colony formation ability, the $\mathrm{CD} 133^{+} \mathrm{CD}_{4}{ }^{+}$percentages, and tumorsphere formation. (A) Relative YAP1 mRNA expression levels in lv-YAP1/HT-29 and lv-YAP1/Caco-2 cells and their control cells. (B) YAP1 protein expression in lv-YAP1/HT-29 and lv-YAP1/Caco-2 cells and their control cells; $\beta$-actin was used as control. (C and D) The proliferation rates of lv-YAP1/HT-29 (C) and lv-YAP1/Caco-2 cells (D) and their control cells from days 1 through 4 after seeding $\left({ }^{*}: P<0.05,{ }^{* *}: P<0.01\right)$. (E) The colony formation assays indicated that more colonies were formed in lv-YAP1/HT-29 and lv-YAP1/Caco-2 cells compared to their respective control cells $\left.{ }^{* *}: P<0.01\right)$. (F) Flow cytometry of in lv-YAP1/HT-29, lv-YAP1/Caco-2 cells and their control cells. (G) Tumorsphere formation in lv-YAP1/HT-29, lv-YAP1/Caco-2 cells and their control cells. (H) The cell numbers per tumorsphere in lv-YAP1/HT-29 and lv-YAP1/Caco-2 cells were significantly higher than their respective control cells $\left({ }^{* *}: P<0.01\right)$. 
levels were increased significantly in lv-YAP1/HT-29 and lv-YAP1/Caco-2 cells compared with their respective control cells (Figures 5). YAP1 nuclear translocation and accumulation were predominant in both lv-YAP1/HT29 and lv-YAP1/Caco-2 cells (Figure 5C). The results indicated that YAP1 overexpression in HT-29 and Caco2 cells increased Ascl2 and 'stemness'-associated genes expression and KLF5 protein level.

To investigate whether Ascl2 mediated YAP1induced 'stemness'-associated genes expression, we performed Ascl2 interference in lv-YAP1/HT-29 and lv-

A

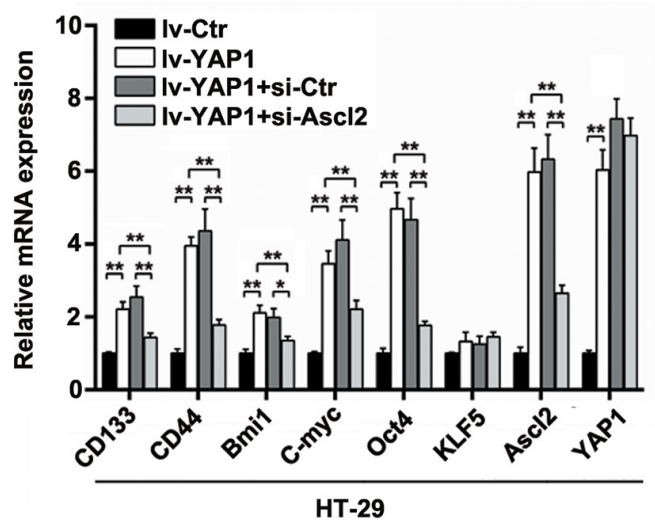

C

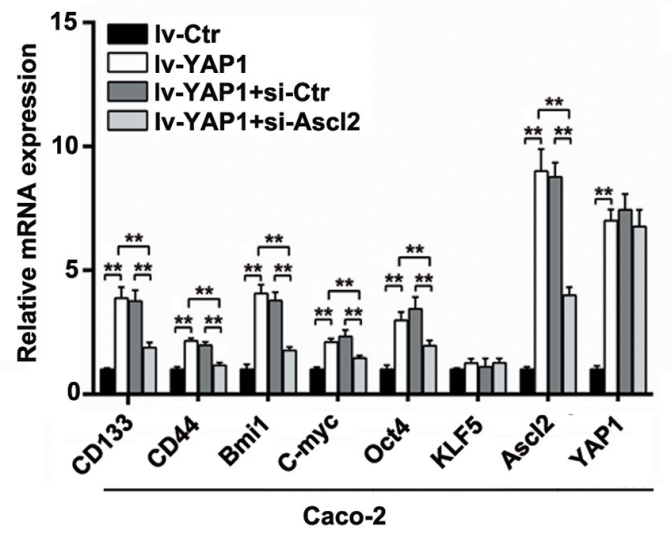

YAP1/Caco-2 cells. The Ascl2-interfered lv-YAP1/HT-29 or lv-YAP1/Caco-2 cells exhibited a significant reversal in 'stemness'-associated genes expression compared their control cells (Figure 5).

\section{YAP1 and KLF5 combined and bound to Ascl2 promoter}

There were four loci in the Ascl2 promoter that had a GC-box (GGGCGG), which are potential binding sites for KLF5 [41]. YAP1 is a transcriptional co-activator and

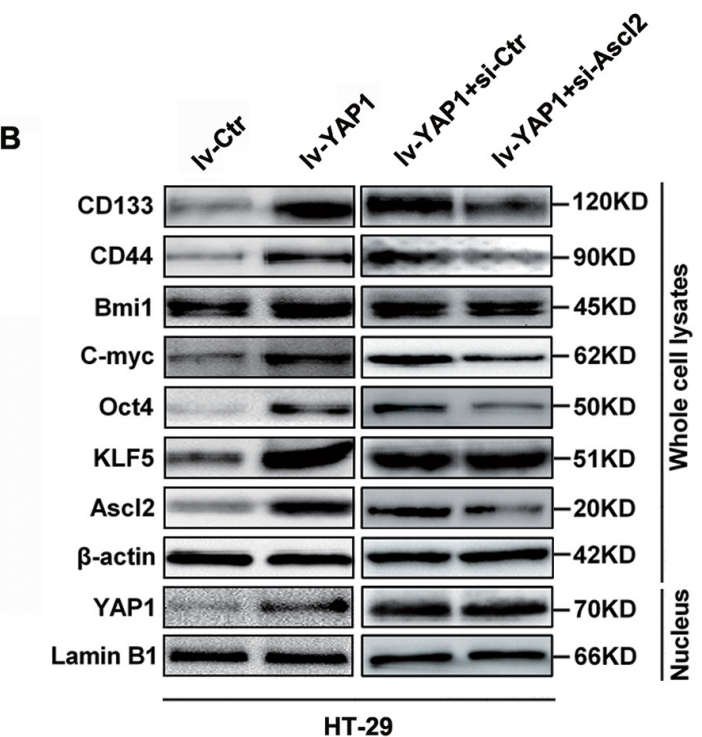

D

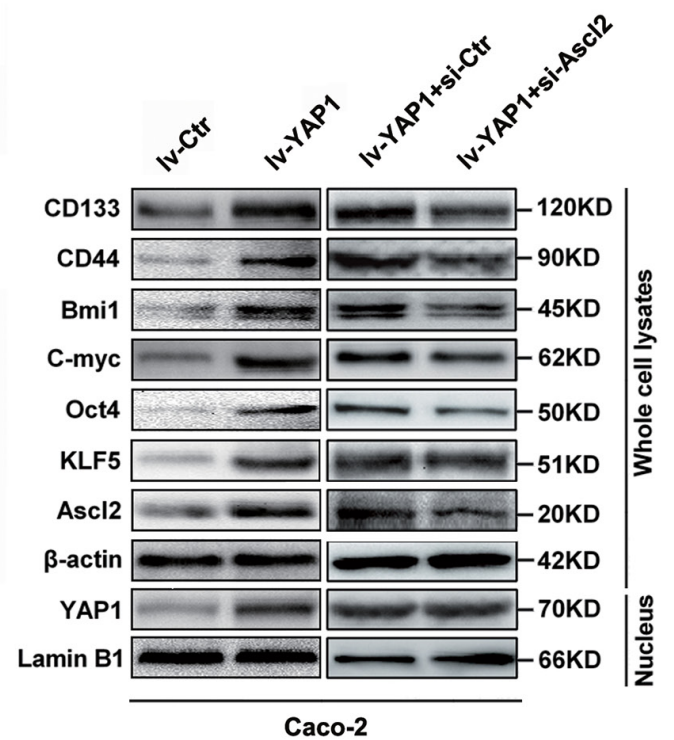

Figure 5: YAP1-enforced expression in HT-29 and Caco-2 cells increased Ascl2, KLF5 and 'stemness'-associated genes expression, which were attenuated by Ascl2 knockdown. (A and B) Relative Ascl2, KLF5 and 'stemness'-associated genes expression levels in both mRNA (A) and protein (B) in YAP1 enforced expressed HT-29, and further Ascl2 interfered lv-YAP1/HT-29 cells. (C and D) Relative Asc12, KLF5 and 'stemness'-associated genes expression levels in both mRNA (C) and protein (D) in YAP1 enforced expressed Caco-2, and further Ascl2 interfered lv-YAP1/ Caco-2 cells. YAP1 nuclear accumulation was based on the blotting using the extracted nuclear proteins in relative cells. $\beta$-actin was used as a loading control, Lamin B1 was used as an internal control for the nuclear fraction. 
has been reported to bind with KLF5 in breast cells [40]. We performed the co-immunoprecipitation assay using antiKLF5 or anti-YAP1 antibodies, the immunoprecipitants of anti-KLF5 or anti-YAP1 antibodies in HT-29 and Caco-2 cells can be detected by both anti-KLF5 and antiYAP1 antibodies (Figures 6A-6D). Four loci within the Ascl2 promoter that had a GC-box (GGGCGG) were selected for chromatin immunoprecipitation (ChIP) assay. Chromatin isolated from YAP1-interfered CD133 ${ }^{+} \mathrm{CD} 44^{+}$ HT-29 or Caco-2 cell population and their control cells was subjected to immunoprecipitation using $\operatorname{IgG}$ and a rabbit polyclonal IgG against KLF5 and IgG and a rabbit polyclonal IgG against YAP1. Binding at the first two loci that contained a GC-box in YAP1-interfered $\mathrm{CD} 133^{+} \mathrm{CD} 44^{+}$
A
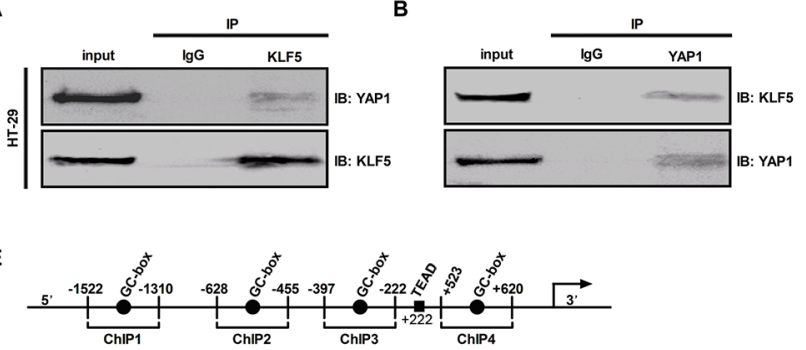

$\mathbf{F}$

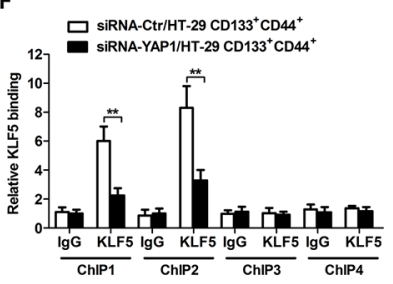

G

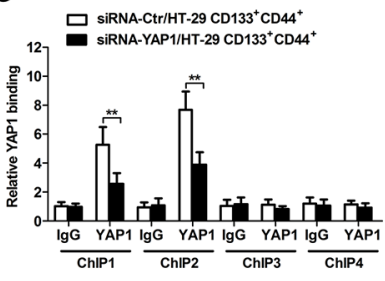

J
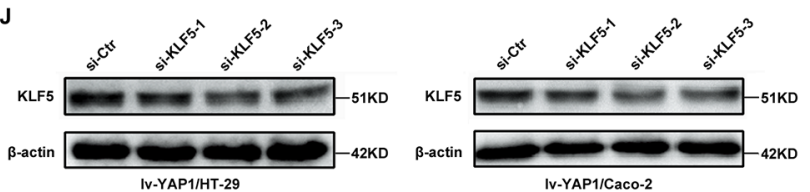

K

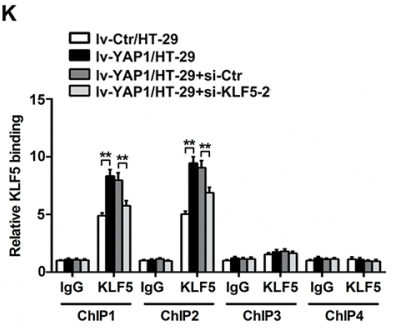

L

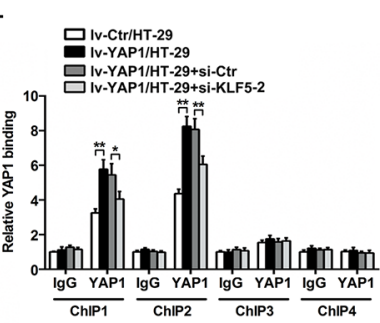

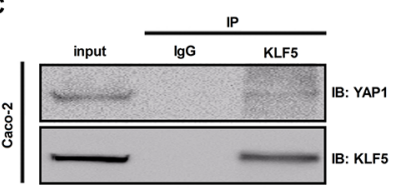

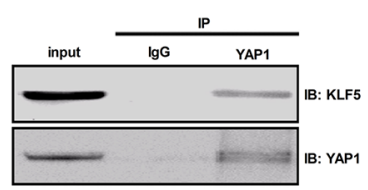

H

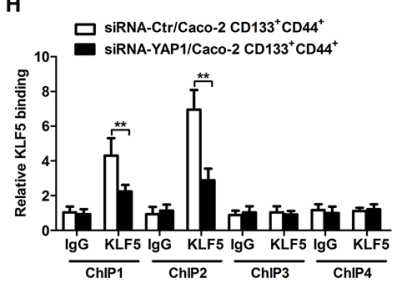

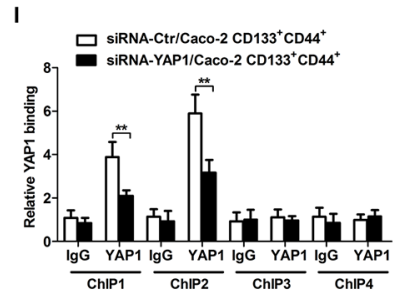

M

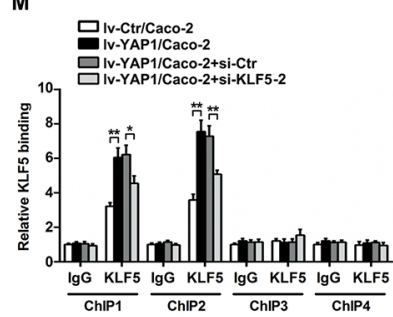

$\mathbf{N}$

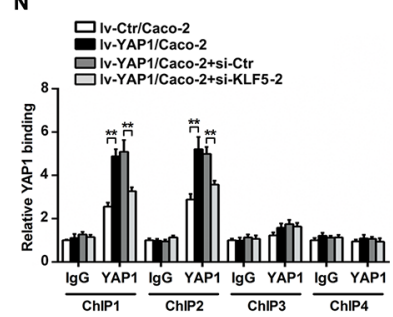

Figure 6: YAP1 and KLF5 combined and bound to the human Ascl2 promoter. (A-D) Co-immunoprecipitation using antiKLF5 (A and C) or anti-YAP1 (B and D) antibodies in the cell lysates from HT-29 (A and B) and Caco-2 (C and D) cells indicated that the immunoprecipitants of anti-KLF5 or anti-YAP1 antibodies in HT-29 and Caco-2 cells can be detected by both anti-KLF5 and antiYAP1 antibodies. (E) A schematic representation of the human Ascl2 promoter. Four loci in the Ascl2 promoter that had a GC-box mutant (AAGTAG) (ChIPs 1-4) were tested and there was a potential TEAD (TEA domain family members (TEAD1-TEAD4)) binding sequence residing at +222 in the Ascl 2 promoter. (F and G) Chromatin isolated from YAP1-interfered CD133 ${ }^{+} \mathrm{CD} 44^{+} \mathrm{HT}-29$ cell population and their control cells were subjected to immunoprecipitation using IgG and a rabbit polyclonal IgG against KLF5 (F) and IgG and a rabbit polyclonal IgG against YAP1 (G). The binding at the first two loci that had GC-boxes in YAP1-interfered CD133 ${ }^{+} \mathrm{CD} 44^{+}$HT- 29 cell population was significantly reduced compared with the control cells $\left({ }^{* *}: P<0.01\right.$ ). (H and I) ChIP assays using YAP1-interfered CD $133^{+} \mathrm{CD} 44^{+}$Caco-2 cell population and their control cells indicated that both KLF5 and YAP1 binding at the first two loci that had GC-boxes in YAP1-interfered $\mathrm{CD} 133^{+} \mathrm{CD} 44^{+} \mathrm{HT}-29$ cell population were significantly reduced compared with the control cells $\left({ }^{* *}: P<0.01\right)$. (J) Western blots of KLF5 in lv-YAP1/HT-29 and lv-YAP1/Caco-2 cells that were transiently transfected with KLF5 siRNA1 (si-KLF5-1), siRNA2 (si-KLF5-2) or siRNA3 (si-KLF5-3); $\beta$-actin was used as a loading control. (K-N) ChIP assays using lv-YAP1/HT-29 and si-KLF5-2 transfected lv-YAP1/ HT-29 cells ( $\mathrm{K}$ and $\mathrm{L}$ ), and lv-YAP1/Caco-2 and si-KLF5-2 transfected lv-YAP1/Caco-2 cells (M and N) cells and their control cells indicated that both KLF5 and YAP1 binding at the first two loci that had GC-boxes in 1v-YAP1/HT-29 and lv-YAP1/Caco-2 cells was significantly increased compared with their respective control cells, KLF5 interference in lv-YAP1/HT-29 and lv-YAP1/Caco-2 cells led to the significant reduction of KLF5 or YAP1 binding to the human Ascl2 promoter $\left({ }^{*}: P<0.05,{ }^{* *}: P<0.01\right)$. 
HT-29 or Caco-2 cell population was significantly reduced compared with their respective control cells (Figures 6F6I). In order to confirm whether KLF5 depletion reduces YAP1 binding and Ascl2 luciferase reporter activity upon YAP1 overexpression, we firstly observed the interference efficiency of three different KLF5 siRNAs in Lv-YAP1/ HT-29 or Lv-YAP1/Caco-2 cells and confirmed si-KLF5-2 was the most efficient sequence to inhibit KLF5 expression (Figure 6J). ChIP assays using lv-YAP1/HT-29, lv-YAP1/ Caco-2 cells and their respective control cells indicated that both KLF5 and YAP1 binding at the first two loci that had a GC-box was significantly increased compared with control cells (Figures 6J-6M). ChIPs 3 and 4 in both YAP1interfered $\mathrm{CD} 133^{+} \mathrm{CD} 44^{+} \mathrm{CRC}$ cell population and YAP1enforced expressed CRC cells gave negative results, which indicated that both KLF5 and YAP1 bound to the first two loci that had a GC-box, but did not bind the other two loci. KLF5 knockdown in Lv-YAP1/HT-29 or Lv-YAP1/Caco-2 cells reversed the increased YAP1 or KLF5 binding to Ascl2 promoter upon YAP1 overexpression (Figures 6K-6N).

\section{Transcriptional regulation of Ascl2 by YAP1}

We produced a series of pGL3-Basic firefly luciferase reporters containing different truncated versions of Ascl2 promoter (Figure 7A). A reduction in Ascl2 promoter activity was evident from the luciferase reporter assay involving Ascl2 promoter $(-2588 /+620)$ in YAP1-interfered CD133 ${ }^{+}$CD $44^{+}$HT-29 and Caco- 2 cells compared with their respective controls (Figures $7 \mathrm{~B}$ and 7C). Then, we compared the abilities of the truncated promoters to drive Asc12 expression in YAP1-interfered CD $133^{+} \mathrm{CD}_{44}{ }^{+} \mathrm{HT}-29$ and Caco- 2 cells, and significantly lower luciferase activity was observed in YAP1-interfered CD $133^{+} \mathrm{CD}_{4}{ }^{+}$HT-29 and Caco- 2 cells when using the pGL3-Ascl2 promoter $(-628 /+620)$. However, no difference in luciferase activity using the pGL3-Ascl2 promoter $(-82 /+620)$ (Figures $7 \mathrm{~B}$ and $7 \mathrm{C})$ was observed. The results indicated that the first three GC-boxes might be responsible for the transcriptional regulation of the Ascl2 gene, and only the region containing the first two GC-boxes can be bound by KLF5 and YAP1 based on ChIP assays. Thus, the first two GC-boxes in the Ascl2 promoter region were used for the transcriptional regulation of Ascl2 by KLF5 and YAP1.

The inserted Ascl2 promoter in pGL3 vector (wildtype reporter, GC-box wt, pGL3-p2) contained a second potential KLF5 binding site (GGGCGG), and the second GC-box was mutated to GC-box mutant (AAGTAG) (GCbox mt) (Figure 7D). YAP1-interfered CD133 ${ }^{+} \mathrm{CD} 44^{+} \mathrm{HT}-$ 29 and Caco- 2 cells and their control cells were transfected with Ascl2 promoter-Luc construct (GC-box wt) and its mutant (GC-box mt) and there were reduced Ascl2 promoter activities in YAP1-interfered $\mathrm{CD} 133^{+} \mathrm{CD} 44^{+} \mathrm{HT}$ 29 and Caco- 2 cells compared with their control cells, GCbox $\mathrm{mt}$ led to a significant reduction of $\mathrm{Ascl} 2$ promoter activities in both YAP1-interfered $\mathrm{CD} 133^{+} \mathrm{CD} 44^{+} \mathrm{HT}-29$ and Caco- 2 cells and their control cells (Figures 7E and 7F).

A significant increase of Ascl2 promoter activity when using pGL3-p2 or pGL3-p3 was evident in 1vYAP1/HT-29 and lv-YAP1/Caco-2 cells compared with their control cells. KLF5 knockdown in Lv-YAP1/HT-29 and Lv-YAP1/Caco-2 cells reversed the Ascl2 promoter activities upon YAP1 overexpression (Figures $7 \mathrm{G}$ and $7 \mathrm{H}$ ). GC-box mutation led to a significant reduction of Ascl2 promoter activities in Lv-YAP1/HT-29 and Lv-YAP1/ Caco-2 cells, and KLF5 knockdown using si-KLF5-2 further reduced Ascl2 promoter activities (Figures 7I and $7 \mathrm{~J})$.

\section{Correlation between Ascl2 and YAP1 expression levels in CRC samples}

To verify whether Ascl 2 expression levels in human CRC samples were related to YAP1 expression levels, quantitative real-time PCR was used to quantify Ascl2 mRNA as well as YAP1 mRNA levels in 52 CRC samples and their normal mucosa. Ascl2 and YAP1 mRNA levels in cancerous tissues were significantly higher than those in normal mucosa (Figures 8A and 8B). The Ascl2 mRNA expression was correlated with YAP1 expression (Figure 8C) in human CRC samples.

\section{DISCUSSION}

We demonstrated for the first time that the Hippo coactivator YAP1 was a molecular conveyor of selfrenewal properties in $\mathrm{CRC}$ progenitor cells and Ascl2 can be activated by the Hippo signaling pathway in CRC progenitor cells, which ensures the self-renewability of CRC progenitor cells. YAP1 directly activated Asc12 transcription in concert with its sequence-specific DNA binding partner KLF5.

The Hippo signaling pathway is gaining recognition as an important player in both organ size control and carcinogenesis because the disruption of the core kinase cascade initiated by Hippo and the phosphorylation of YAP/TAZ (Mst1/2, Sav1 and Lats1/2 and YAP1) can lead to carcinogenesis [42-44]. YAP1, an effector of the Hippo signaling pathway, has been reported as an oncogene in several tumor types [45-47]. TAZ (a transducer of the Hippo pathway) is required for breast CSCs to sustain self-renewal and tumor-initiation capacities [48]. The reciprocal regulation of tumor-initiating stem-like cells by TLR4, and TGF- $\beta$ requires YAP1 and IGF2BP3 in hepatocellular carcinoma (HCC) [49]. Although YAP binding with $\beta$-catenin and TBX5 is thought as being central to the mechanism for YAP1-mediated regulation of Wnt/ $\beta$-catenin signaling $[34,36]$, our observations in this study identified a novel mechanism that YAP1 could confer CRC progenitor cell properties via combination 
with KLF5 and bound to the KLF5 binding site (GC-box) in the Ascl2 promoter induced its transcriptional activation (Figure 8D).

Ascl 2 plays a critical role in intestinal stem cells, CRC progenitor cells and human colorectal cancer [1014] and is also overexpressed in gastric cancer and lung squamous cell carcinoma. It can accelerate cell growth, increase tumor resistance to 5-FU, and be regarded

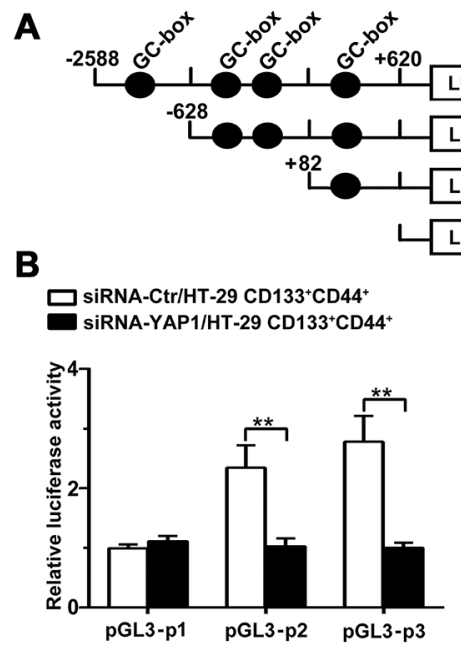

G
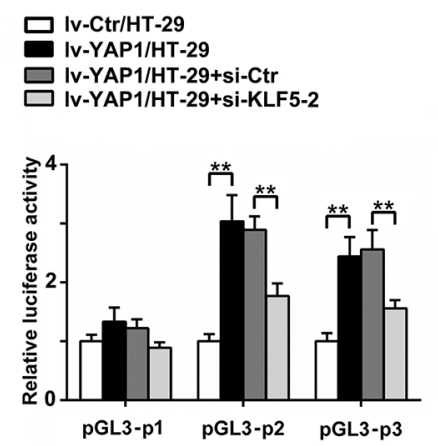

as an independent prognostic indicator [50, 51]. We have now provided evidence that YAP1-activated Ascl2 confered the acquisition of YAP1-induced CRC progenitor cell self-renewal properties. YAP1 and Ascl2 may facilitate transformation by the co-regulation of downstream targets or by the activation of distinct targets that synergize to promote the transformed phenotype.
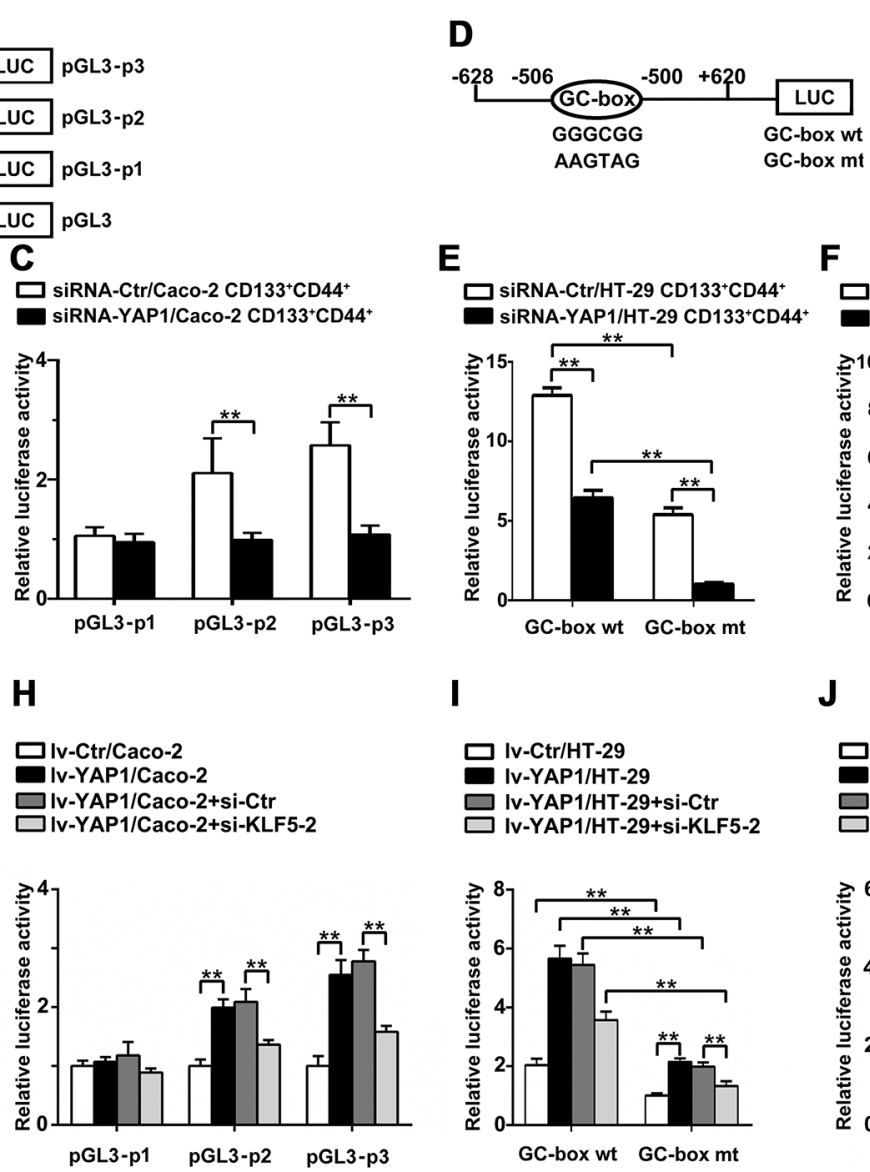

E
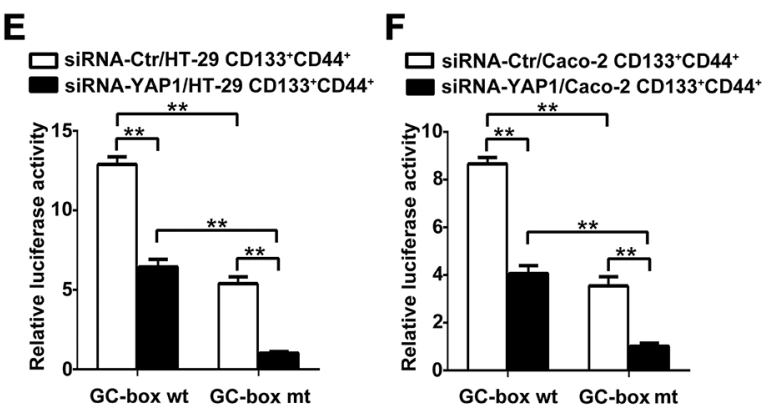

I
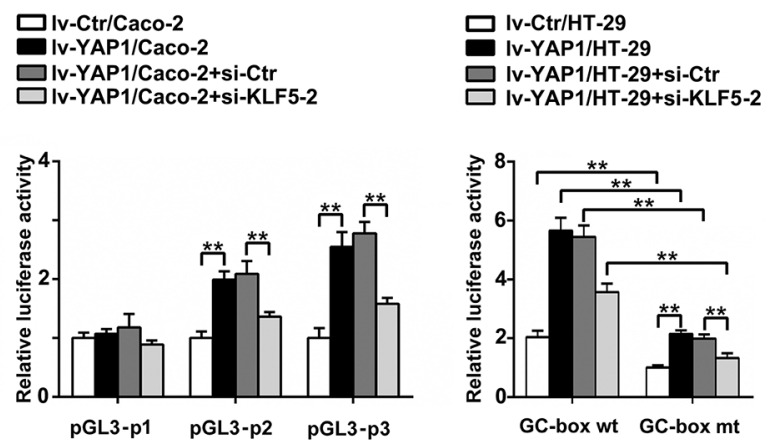

J

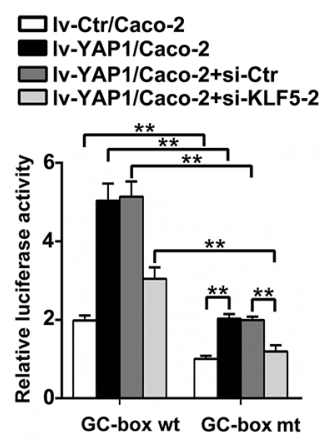

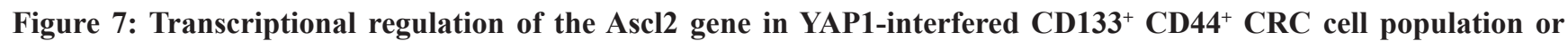
YAP1-enforced expressed HT-29 or Caco-2 cells. We performed luciferase assays using YAP1-interfered CD133 ${ }^{+} \mathrm{CD} 44^{+} \mathrm{CRC}$ cell population to analyze the transcriptional regulation of the Ascl2 gene. (A) We produced a series of pGL3-Basic firefly luciferase reporters containing different human Asc12 promoters encompassing bp -2588 to +620 (pGL3-p3), -628 to +620 (pGL3-p2), and -82 to +620 (pGL3-p1). The black dots represent GC-boxes. (B and C) A reduction of Ascl2 promoter activity was evident from the luciferase reporter assays in YAP1-interfered $\mathrm{CD} 133^{+} \mathrm{CD} 44^{+} \mathrm{HT}-29$ (B) and Caco-2 (C) cell population compared with their controls $(\mathrm{n}=3)\left({ }^{* *}\right.$ : $P<0.01)$. (D) A schematic representation of human Ascl2 promoter $(-628$ to +620$)$ constructs containing the second potential KLF5 binding site, GC-box (GGGCGG) (GC-box wt), that was used in this study; the GC-box was mutated to GC-box mutant (AAGTAG) (GC-box mt). (E and F) YAP1-interfered CD133 ${ }^{+} \mathrm{CD} 44^{+} \mathrm{HT}-29$ (E) and Caco-2 (F) cell population and their control cells were transfected with the Ascl2 promoter-Luc construct (GC-box wt) or its mutant (GC-box mt). Reduced Ascl2 promoter activity was evident based on luciferase reporter assays $(\mathrm{n}=3)\left({ }^{* *}: P<0.01\right)$. ( $\mathbf{G}$ and $\left.\mathbf{H}\right)$ A significant increase in Ascl2 promoter activity was evident based on the luciferase reporter assays in lv-YAP1/HT-29 (G) and lv-YAP1/Caco-2 (H) cells compared with their controls ( $\mathrm{n}=3$ ), KLF5 interference in lv-YAP1/HT-29 (G) and lvYAP1/Caco-2 $(\mathrm{H})$ cells led to the significant reduction of Ascl2 promoter activity compared with their control cells $\left({ }^{* *}: P<0.01\right)$. (I and $\left.\mathbf{J}\right)$ The lv-YAP1/HT-29 (I) and lv-YAP1/Caco-2 (J) cells and their control cells were transfected with the Ascl2 promoter-Luc construct (GCbox wt) and its mutant (GC-box mt). GC-box mutation led to the significant reduction of Ascl2 promoter activities based on the luciferase reporter assays (n=3), KLF5 interference in lv-YAP1/HT-29 (I) and lv-YAP1/Caco-2 (J) cells led to further reduction of Asc12 promoter activity compared with their control cells which were transfected with the Ascl2 promoter-Luc construct (GC-box wt) or its mutant (GCbox mt) $\left.{ }^{* *}: P<0.01\right)$. 
The canonical $\mathrm{Wnt} / \beta$-catenin signaling regulates many biological processes, including cell proliferation, cell fate decision, axis formation, and organ development during embryonic development and tissue homeostasis, it plays a critical roles as a driver of colon cancer $[8,10]$. RNF43, ZNRF3, RSPO2 or RSPO3 alterations in breast, colorectal, gastric, pancreatic and other cancers activate the Wnt/ $\beta$-catenin signaling. Gain-of-function mutations in the CTNNB1 gene, as well as loss-of-function mutations in the APC and AXIN2 genes, activate the canonical Wnt/ $\beta$-catenin signaling cascade that regulates self-renewal, survival, proliferation and differentiation of tumor cells [52]. It is known that YAP1/TAZ can regulates Wnt/ $\beta$-catenin signaling via binding with Dishevelled, $\beta$-catenin, or TBX5, or inducing the Wnt inhibitor DKK1 $[34,36,52]$. These reports suggest that the Hippo signaling pathway regulates $\mathrm{Wnt} / \beta$-catenin signaling through multiple mechanisms, depending on biological context.
As a coactivator, YAP1 has been reported to regulate a series of genes, such as EGFR, ITGB2, CTGF, SOX9, ALPP, PIK3C2B, AREG, and BIRC5 [48, 53, 54]. The similarity of these studies is that YAP1-regulated transcription depends on transcription factor partners, such as TEAD, p73, ErbB4, and RUNX2 [55]. In this study, our initial observation is that YAP1 combined with KLF5 in HT-29 and Caco-2 cells, bound to the proximal Ascl2 promoter and induced its transcriptional activation. YAP1enforced expression in HT-29 and Caco-2 cells did not increase KLF5 mRNA levels but significantly increased KLF5 protein levels, this result indicated that YAP1 did not transcriptionally induce KLF5 expression but possibly prevented KLF5 degradation, which is supported by a series of studies [39, 40]. KLF5 is an important transcription factor that is involved in regulating a larger number of genes, and KLF5 potentially functions as an oncogene [56]. Multicellular tumor spheroid (MCTS) formation in HT-29 colon carcinoma cells required high
A

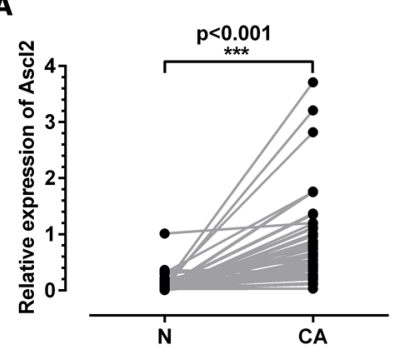

B

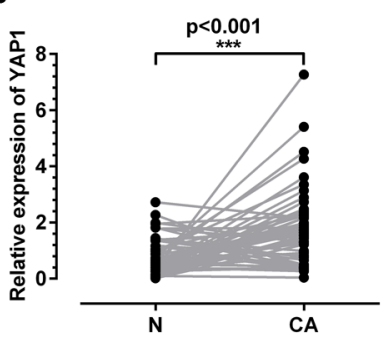

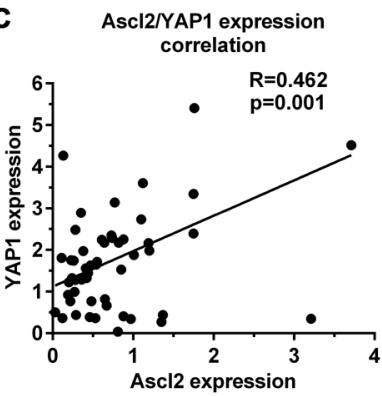

D

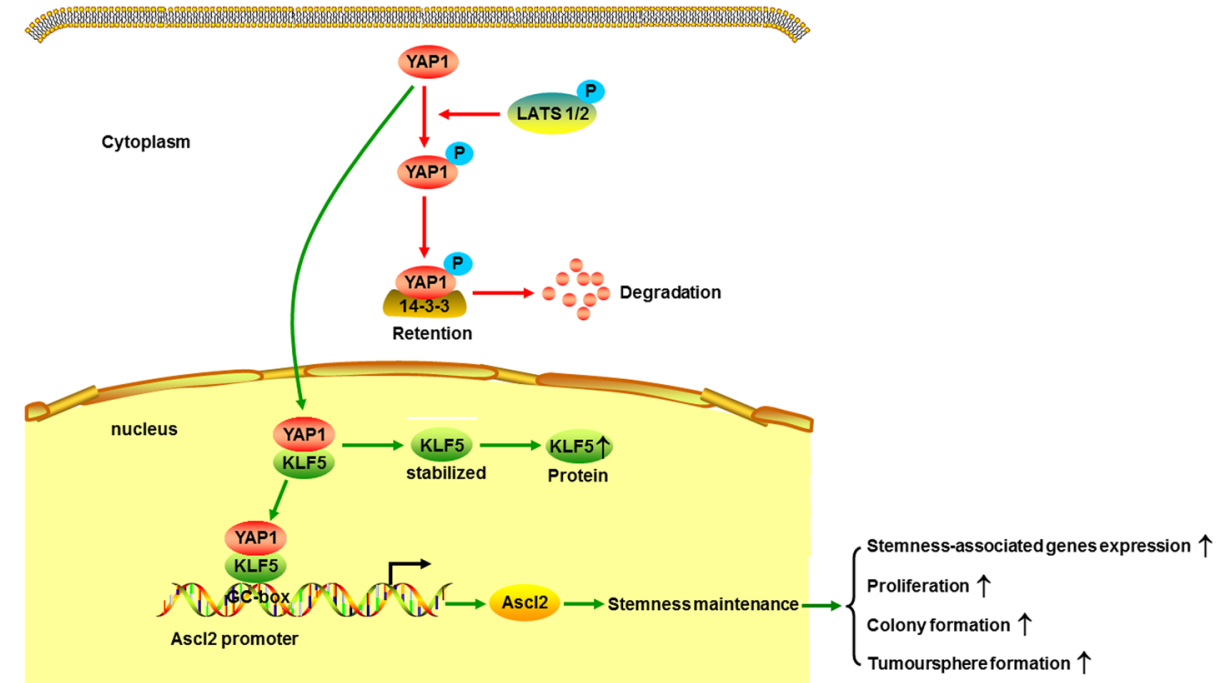

Figure 8: Correlation between Ascl2 and YAP1 mRNA levels in human colorectal carcinoma tissues and a working model of how YAP1 activated Ascl2 expression and ensured the self-renewability of colon cancer progenitor cells. Quantitative real-time PCR was performed in CRC tissues (CA) and their peri-cancerous mucosa (N) to assess Ascl2 and YAP1 KLF5 mRNA levels. Asc12 (A) and YAP1 (B) mRNA levels were higher in CRC samples when compared with those in the peri-cancerous mucosa. Ascl2 expression in CRC tissues was positively correlated with YAP1 expression $(P=0.001)$ (C). A working model detailing YAP1 activated Asc12 and ensured the self-renewability of colon cancer progenitor cells. YAP1 was either modified by phosphorylation or not (Phosphorylated YAP1 was represented via the red route, whereas YAP1 without phosphorylation was represented via the green route) (D). 
Table 1: Sequences of the oligonucleotides used for qPCR and chromatin immunoprecipitation (ChIP)

\begin{tabular}{|c|c|}
\hline qPCR & $5^{\prime} \rightarrow 3^{\prime}$ \\
\hline Ascl2 & $\begin{array}{l}\text { F: 5'-CGTGAAGCTGGTGAACTTGG-3' } \\
\text { R: 5'-GGATGTACTCCACGGCTGAG-3' }\end{array}$ \\
\hline CD133 & $\begin{array}{l}\text { F: 5'-TTCTTGACCGACTGAGACCCA-3' } \\
\text { R: 5'-TCATGTTCTCCAACGCCTCTT-3' }\end{array}$ \\
\hline CD44 & $\begin{array}{l}\text { F: 5'-CTGCCGCTTTGCAGGTGTA-3' } \\
\text { R: 5'-CATTGTGGGCAAGGTGCTATT-3' }\end{array}$ \\
\hline Bmil & $\begin{array}{l}\text { F: 5'-CGTGTATTGTTCGTTACCTGGA-3', } \\
\text { R: 5'-TTCAGTAGTGGTCTGGTCTTGT-3' }\end{array}$ \\
\hline C-myc & $\begin{array}{l}\text { F: 5'-GGCTCCTGGCAAAAGGTCA-3' } \\
\text { R: 5'-CTGCGTAGTTGTGCTGATGT-3' }\end{array}$ \\
\hline Oct4 & $\begin{array}{l}\text { F: 5'-CTGGAGAAGGAGAAGCTGGA-3' } \\
\text { R: 5'-CAAATTGCTCGAGTTCTTTCTG-3' }\end{array}$ \\
\hline KLF5 & $\begin{array}{l}\text { F: 5'-AAGGAGTAACCCCGATTTGG-3' } \\
\text { R: 5'-TGGCTTTTCACCAGTGTGAG-3' }\end{array}$ \\
\hline YAP1 & $\begin{array}{l}\text { F: 5'-TAGCCCTGCGTAGCCAGTTA-3', } \\
\text { R: 5'-TCATGCTTAGTCCACTGTCTGT-3' }\end{array}$ \\
\hline MST1 & $\begin{array}{l}\text { F: 5'-AGTGCCAAAGGAGTGTCAATAC-3' } \\
\text { R: 5'-GGATTCCTGGCGTTTCAGTTTC-3' }\end{array}$ \\
\hline$\beta$-actin & $\begin{array}{l}\text { F: 5'-TTGCCGACAGGATGCAGAA-3', } \\
\text { R: 5'-GCCGATCCACACGGAGTACT-3' }\end{array}$ \\
\hline ChIP & $5^{\prime} \rightarrow 3^{\prime}$ \\
\hline ChIP1 & $\begin{array}{l}\text { F: 5'-TCAGACCAGGGACAGGGAG-3' } \\
\text { R: 5'-GGCCGGAAGAGTAGCACC-3' }\end{array}$ \\
\hline ChIP2 & $\begin{array}{l}\text { F: 5'-CTGGCACAAGGCGGTCGG-3' } \\
\text { R: 5'-TGAGGCGGGGTGGGAGGTT-3' }\end{array}$ \\
\hline ChIP3 & $\begin{array}{l}\text { F: 5'-CCCAGTAGATTAACGCACAG-3' } \\
\text { R: 5'-GCCCCATTGAGGAAGC-3' }\end{array}$ \\
\hline ChIP4 & $\begin{array}{l}\text { F: 5'-GCCACAGTTTTCCCCGTCGCCTCC-3' } \\
\text { R: 5'-GCATCCACCCGCCCGCTCCA-3' }\end{array}$ \\
\hline $\begin{array}{l}\text { GAPDH (ChIP for } \\
\text { positive control) }\end{array}$ & $\begin{array}{l}\text { F: 5'-TACTAGCGGTTTTACGGGCG-3' } \\
\text { R: 5'-TCGAACAGGAGGAGCAGAGAGCGA-3' }\end{array}$ \\
\hline
\end{tabular}

KLF5 expression, and tumor formation can be inhibited by KLF5 knockdown [57]. We analysed the Ascl2 promoter $(-2588 \sim+620)$ and found a potential TEAD (TEA domain family members (TEAD1-TEAD4)) binding sequence residing at +222 of Ascl2 promoter (Figure $6 \mathrm{E}$ ). This potential TEAD sequence is not involved with the activation of Ascl2 gene upon YAP1 overexpression, because the Ascl2 luciferase reporter activity (Figure 7A7C) was unaltered although YAP1 overexpression,
The accordant increase of YAP1 and Ascl2 in human colon cancer samples was consistent with the observations in vitro. This indirect in vivo evidence, together with the in vitro results, strengthens our hypothesis for a role of YAP1 in the regulation of Ascl2.

Taken together, we suggest that YAP1/KLF5activated Ascl2 expression in colon cancer progenitor cells confers their self-renewability. This novel mechanism provides a possible target for colon cancer progenitor cells. 
Table 2: The primary antibodies used in the experiment

\begin{tabular}{|c|c|c|}
\hline Primary antibody & Company & Dilution \\
\hline Mouse monoclonal IgG to Ascl2 & Millipore(MAB4418) & WB: $1: 500$ \\
\hline Rabbit polyclonal IgG to CD133 & Proteintech(18470-1-AP) & WB: $1: 500$ \\
\hline Rabbit polyclonal IgG to CD44 & Proteintech(15675-1-AP) & WB: $1: 200$ \\
\hline Rabbit polyclonal IgG to Bmil & Proteintech (10832-1-AP) & WB: $1: 500$ \\
\hline Rabbit polyclonal IgG to C-myc & Proteintech(10828-1-AP) & WB: $1: 500$ \\
\hline Rabbit polyclonal IgG to Oct4 & Proteintech(11263-1-AP) & WB: $1: 500$ \\
\hline Rabbit polyclonal IgG to KLF5 & Proteintech(21017-1-AP) & WB: $1: 500$ \\
\hline Rabbit polyclonal IgG to KLF5 & Santa Cruz Biotechnology(sc-22797) & $\begin{array}{l}\text { IP: } 1: 50 \\
\text { ChIP }\end{array}$ \\
\hline Rabbit polyclonal IgG to YAP1 & Proteintech(13584-1-AP) & WB: $1: 500$ \\
\hline Rabbit monoclonal IgG to YAP1 & Cell Signaling(\#14074) & $\begin{array}{l}\text { IP: } 1: 50 \\
\text { ChIP }\end{array}$ \\
\hline Rabbit polyclonal IgG to MST1 & Cell Signaling(\#3682) & WB: $1: 1000$ \\
\hline $\begin{array}{l}\text { Rabbit monoclonal IgG to } \\
\text { Phospho-YAP(Ser127) }\end{array}$ & Cell Signaling(\#13008) & WB: $1: 1000$ \\
\hline Mouse monoclonal IgG to $\beta$-actin & Proteintech(66009-1-Ig) & WB: $1: 4000$ \\
\hline Rabbit polyclonal IgG to Lamin B1 & Proteintech(12987-1-AP) & WB: $1: 5000$ \\
\hline pGL3-Ascl2-promotor & $5^{\prime} \rightarrow 3^{\prime}$ & Length of product \\
\hline$-2588 /+620$ & $\begin{array}{l}\text { F: 5' -ggggtace TCCGGAGATCTTACCA-3' } \\
\text { R: 5' -cggctagc CGCGCCTGCATCCAC-3' }\end{array}$ & $3208 \mathrm{bp}$ \\
\hline$-628 /+620$ & $\begin{array}{l}\text { F:5' -ggggtacc GACCGTCCTGGCACAAG-3' } \\
\text { R: 5' -cggctagc CGCGCCTGCATCCAC-3' }\end{array}$ & $1248 \mathrm{bp}$ \\
\hline$-82 /+620$ & $\begin{array}{l}\text { F: 5'-ggggtacc GATCTTGCGCGCCTC-3' } \\
\text { R: 5'-cggctagc CGCGCCTGCATCCAC-3' }\end{array}$ & 702 bp \\
\hline
\end{tabular}

The underlined parts in the primers are KpnI and NheI adaptors.

\section{MATERIALS AND METHODS}

\section{Cell culture}

The HT-29 and Caco-2 human colonic adenocarcinoma cell lines were obtained from the American Type Culture Collection (ATCC) and routinely cultured in McCoy's 5A medium (Sigma, USA) supplemented with $10 \%$ fetal bovine serum (FBS; HyClone, USA) at $37^{\circ} \mathrm{C}$ in a $5 \% \mathrm{CO}_{2}$ humidified incubator.

\section{Flow cytometry cell sorting and flow cytometry analysis}

The single-cell suspensions of HT-29 and Caco-2 cells were incubated with APC-conjugated anti-human CD133 antibody (Miltenyi Biotec) and FITC-conjugated anti-human CD44 antibody (Miltenyi Biotec) in PBS for $10 \mathrm{~min}$ at $4^{\circ} \mathrm{C}$. The APC-conjugated mouse IgG2b isotype control antibody (Miltenyi Biotec) and the FITCconjugated mouse IgG1 isotype control antibody (Miltenyi Biotec) served as negative controls. The CD $133^{+} / \mathrm{CD} 44^{+}$ and CD133-CD44- cell population was sorted using a fluorescence-activated cell sorter (BD Aria, USA).

\section{Cell proliferation}

Isolated cells were seeded at 10000 cells/well in 24-well plates. Then, $20 \mu \mathrm{l}$ of CCK-8 solution (Beyotime Biotechnology, China) was added to each well and cultured at $37^{\circ} \mathrm{C}$ for $4 \mathrm{~h}$. On the $1 \mathrm{st}, 2 \mathrm{nd}$, 3rd and 4 th days, the absorbance was measured using a microplate reader (Thermo, USA) at $450 \mathrm{~nm}$. The experiments were repeated in triplicate. 


\section{Colony formation assay}

An equal number of viable cells were seeded at a density of 1000 cells/well in 6-well plates. After incubating for 14 days at $37^{\circ} \mathrm{C}$, the colonies that adhered to the bottoms of the plates were counted using an inverted microscope (Olympus, Japan).

\section{Tumorsphere formation}

To evaluate the tumorsphere-formation potential, when single cells reached a density of 1000 cells, they were plated in 48-well ultra-low attachment plates (Corning Inc, USA) with DMEM/F12 (HyClone, USA) serum-free media supplemented with B-27 (Gibco, USA), epidermal growth factor (EGF, Peprotech, USA) and basic fibroblast growth factor (bFGF, Peprotech, USA). Every 3 days, fresh medium was added. The experiment was terminated after 7 days, and spheres were quantified using an inverted microscope (Olympus, Japan).

\section{Real-time PCR}

To quantitatively determine the expression levels of each gene, real-time PCR was performed using firststrand cDNA, forward and reverse primers and the SYBR premix Ex TaqTM Green II (TaKaRa, Japan). The primer sequences are summarized in Table 1 , and $\beta$-actin was used as an endogenous control. Expression levels were analyzed using the comparative $\mathrm{Ct}$ method $\left(2^{-\Delta \Delta \mathrm{Ct}}\right)$. The real-time PCR reactions were independently performed in triplicate.

\section{Western blotting}

The cytoplasmic proteins and nuclear proteins were extracted using NE-PER nuclear and cytoplasmic extraction reagents (Thermo, USA). Separated protein bands were transferred onto PVDF membrane, and the membrane were probed overnight at $4^{\circ} \mathrm{C}$ with a primary antibody (Table 2). Protein bands were visualized using the chemiluminescent Pierce ECL kit (Thermo Scientific), and quantification of the Western blots was performed using ChemiDox ${ }^{\mathrm{TM}}$ XRS with Image $\mathrm{Lab}^{\mathrm{TM}}$ software. Detailed Western blotting procedures have been described previously [58].

\section{siRNA transfection}

The $\mathrm{CD} 133^{+} / \mathrm{CD}_{4} 4^{+}$and $\mathrm{CD} 133 \% / \mathrm{CD} 44-$ cell population from HT-29 or Caco-2 cells was seeded in 6-well plates and transfected with YAP1 siRNAs or the scrambled control, and the lv-YAP1/HT-29 and lv-YAP1/ Caco-2 cells were transfected with KLF5 siRNAs or Ascl2 siRNA and their scrambled controls using the FuGENE HD transfection reagent (Promega, USA). The siRNA sequences were designed by GenePharma Co. Ltd. (Shanghai, China). The sequences of the three YAP1 siRNAs were as follows: siRNA-YAP1-1, Forward: 5'-GGUGAUACUAUCAACCAAATT-3', Reverse: 5'-UUUGGUUGAUAGUAUCACCTT-3'; siRNA-YAP1-2, Forward: 5'-CUGCCACCAAGCUAGAUAATT-3', Reverse: 5'-UUAUCUAGCUUGGUGGCAGTT-3'; siRNA-YAP1-3, Forward: 5'-GACGACCAAUAGCUCAGAUTT-3', Reverse: 5'-AUCUGAGCUAUUGGUCGUCTT-3'. The sequences of the three KLF5 siRNAs were as follows: si-KLF5-1, Forward: 5'-GCAGACUGCAGUGAAACAATT-3', Reverse: 5'UUGUUUCACUGCAGUCUGCTT-3', si-KLF5-2, Forward: 5'- GGCAAUUCACAAUCCAAAUTT-3', Reverse: 5'-AUUUGGAUUGUGAAUUGCCTT-3', si-KLF5-3, Forward: 5'-GCAUCCACUACUGCGAUUATT-3', Reverse: 5'-UAAUCGCAGUAGUGGAUGCTT-3'. Ascl2 siRNA was described in previously [23]. The cells were harvested $48 \mathrm{~h}$ after transfection and YAP1 or KLF5 expression was examined.

\section{YAP1 overexpression}

Lentivirus particles expressing YAP1 were produced by GenePharma Co. Ltd. China. HT-29, and Caco-2 cells were transfected with the lentivirus particles using an LV5 vector with a YAP1 insert. Stably transfected cells with GFP were sorted using flow cytometry (BD FACS Aria II; BD Biosciences, Franklin Lakes, NJ, USA) and isolated using puromycin selection (Solarbio, Beijing, China).

\section{Co-immunoprecipitation}

Cell lysates were immunoprecipitated with antiKLF5 (Santa Cruz, SC22797) or anti-YAP1 (Cell Signaling, 14074) polyclonal antibodies according to the instructions of the BeaverBeads ${ }^{\mathrm{TM}}$ Protein A/G Immunoprecipitation Kit (22202-20), separated by SDS/ PAGE and analyzed by Western blotting.

\section{ChIP assays}

ChIP assays were performed using a ChIP assay kit (Millipore, 17408) according to the manufacturer's instructions. Soluble chromatin was prepared from siRNAYAP1-1/HT-29 $\mathrm{CD} 133^{+} / \mathrm{CD}_{4} 4^{+}$or siRNA-YAP1-1/Caco$2 \mathrm{CD} 33^{+} / \mathrm{CD}_{4} 4^{+}$cell population and their control cells as well as lv-YAP1/HT-29 or lv-YAP1/ Caco-2 and their control cells. The chromatin was immunoprecipitated with anti-KLF5 (Santa Cruz, SC22797, USA) or anti-YAP1 (Cell Signaling, 14074, USA). The precipitated DNA was subjected to real-time PCR using specific primers. The primer sequences and the lengths of the amplified PCR products are shown in Table 3.

\section{Transfection and luciferase assays}

The Ascl2 5'-flanking sequence (-2588/+620 bp region), amplified using PCR from intestinal tissue DNA, was inserted into the luciferase reporter vector 
pGL3-Basic (Promega, Madison, WI, USA). The primer pairs used to produce each promoter fragment are listed in Table 3. All transfections were performed using the FuGENE HD transfection reagent (Promega, USA). Luciferase activity was measured $48 \mathrm{~h}$ post-transfection using the Dual-Luciferase Reporter Assay System (Promega) as described in our previous report [59]. The pGL3-Basic vector containing the Ascl2 promoter $(-628 /+620)$ and one GC-Box site (GGGCGG) served as the wild-type construct used for the generation of the Ascl2-Luc mutant, which harbors a mutation in the GC-BOX site (AAGTAG) created by PCR-based sitedirected mutagenesis. The transfection of the luciferase reporters containing the various Ascl2 promoters and the luciferase assays were performed as described in our previous report $[17,59]$.

\section{Tissue samples}

A total of 52 patients with colorectal cancer who were scheduled for colonoscopy or for surgical resection were enrolled in this study. Cancerous samples and their peri-cancerous mucosa were collected by biopsy or from the resection samples. The fresh samples were immediately stored in liquid nitrogen for further quantitation of Asc12, YAP1 and KLF5 mRNA levels using quantitative real-time PCR analysis. This study was approved by the local clinical research ethics committee. All the subjects provided informed consent prior to their colonoscopy or resection surgery.

\section{Statistical analysis}

GraphPad Prism 6.0 software was used for all statistical analyses. The differences were deemed significant when $P<0.05$ and very significant when $P<0.01$.

\section{Author contributions}

The study was conceived and designed by XW and RW. The experiments were performed by XW, JY, YS and HC. The data were analyzed by XW, SL, and LL. The manuscript was written by XW and RW.

\section{ACKNOWLEDGMENTS AND FUNDING}

This work was supported by the following awards: 81500410,81170340 and 81372557 from the National Natural Science Foundation of China.

\section{CONFLICTS OF INTEREST}

The authors declare no conflicts of interest.

\section{REFERENCES}

1. Jemal A, Siegel R, Xu J, Ward E. Cancer statistics, 2010. CA Cancer J Clin. 2010; 60:277-300. https://doi. org/10.3322/caac.20073.

2. Huang EH, Wicha MS. Colon cancer stem cells: implications for prevention and therapy. Trends Mol Med. 2008; 14:503-9. https://doi.org/10.1016/j. molmed.2008.09.005.

3. Tan BT, Park CY, Ailles LE, Weissman IL. The cancer stem cell hypothesis: a work in progress. Lab Invest. 2006; 86:1203-7. https://doi.org/10.1038/labinvest.3700488.

4. O'Brien CA, Pollett A, Gallinger S, Dick JE. A human colon cancer cell capable of initiating tumour growth in immunodeficient mice. Nature. 2007; 445:106-10. https:// doi.org/10.1038/nature05372.

5. Ricci-Vitiani L, Lombardi DG, Pilozzi E, Biffoni M, Todaro $\mathrm{M}$, Peschle C, De Maria R. Identification and expansion of human colon-cancer-initiating cells. Nature. 2007; 445:1115. https://doi.org/10.1038/nature05384.

6. Gangemi RM, Griffero F, Marubbi D, Perera M, Capra MC, Malatesta P, Ravetti GL, Zona GL, Daga A, Corte G. SOX2 silencing in glioblastoma tumor-initiating cells causes stop of proliferation and loss of tumorigenicity. Stem Cells. 2009; 27:40-8. https://doi.org/10.1634/ stemcells.2008-0493.

7. Todaro M, Alea MP, Di Stefano AB, Cammareri P, Vermeulen L, Iovino F, Tripodo C, Russo A, Gulotta G, Medema JP, Stassi G. Colon cancer stem cells dictate tumor growth and resist cell death by production of interleukin-4. Cell Stem Cell. 2007; 1:389-402. https://doi.org/10.1016/j. stem.2007.08.001.

8. Clevers H. The cancer stem cell: premises, promises and challenges. Nat Med. 2011; 17:313-9. https://doi. org/10.1038/nm.2304.

9. de Sousa EM, Vermeulen L, Richel D, Medema JP. Targeting Wnt signaling in colon cancer stem cells. Clin Cancer Res. 2011; 17:647-53. https://doi.org/10.1158/10780432.CCR-10-1204.

10. van der Flier LG, van Gijn ME, Hatzis P, Kujala P, Haegebarth A, Stange DE, Begthel H, van den Born M, Guryev V, Oving I, van Es JH, Barker N, Peters PJ, et al. Transcription factor achaete scute-like 2 controls intestinal stem cell fate. Cell. 2009; 136:903-12. https://doi. org/10.1016/j.cell.2009.01.031.

11. Zhu R, Yang Y, Tian Y, Bai J, Zhang X, Li X, Peng Z, He Y, Chen L, Pan Q, Fang D, Chen W, Qian C, et al. Ascl2 knockdown results in tumor growth arrest by mirna-302brelated inhibition of colon cancer progenitor cells. PLoS One. 2012; 7:e32170. https://doi.org/10.1371/journal. pone. 0032170 .

12. Jubb AM, Chalasani S, Frantz GD, Smits R, Grabsch HI, Kavi V, Maughan NJ, Hillan KJ, Quirke P, Koeppen H. Achaete-scute like 2 (ascl2) is a target of Wnt signalling 
and is upregulated in intestinal neoplasia. Oncogene. 2006; 25:3445-57. https://doi.org/10.1038/sj.onc. 1209382.

13. Jubb AM, Hoeflich KP, Haverty PM, Wang J, Koeppen H. Ascl2 and 11p15.5 amplification in colorectal cancer. Gut. 2011; 60:1606-7; author reply 7. https://doi.org/10.1136/ gut.2010.231746.

14. Stange DE, Engel F, Longerich T, Koo BK, Koch M, Delhomme N, Aigner M, Toedt G, Schirmacher P, Lichter P, Weitz J, Radlwimmer B. Expression of an ASCL2 related stem cell signature and IGF2 in colorectal cancer liver metastases with 11p15.5 gain. Gut. 2010; 59:1236-44. https://doi.org/10.1136/gut.2009.195701.

15. Liu X, Chen X, Zhong B, Wang A, Wang X, Chu F, Nurieva RI, Yan X, Chen P, van der Flier LG, Nakatsukasa $\mathrm{H}$, Neelapu SS, Chen W, et al. Transcription factor achaete-scute homologue 2 initiates follicular T-helpercell development. Nature. 2014; 507:513-8. https://doi. org/10.1038/nature12910.

16. Takao T, Asanoma K, Tsunematsu R, Kato K, Wake N. The maternally expressed gene tssc 3 regulates the expression of MASH2 transcription factor in mouse trophoblast stem cells through the AKT-Sp1 signaling pathway. J Biol Chem. 2012; 287:42685-94. https://doi.org/10.1074/jbc. M112.388777.

17. Shang Y, Pan Q, Chen L, Ye J, Zhong X, Li X, Meng L, Guo J, Tian Y, He Y, Chen W, Peng Z, Wang R. Achaete scutelike 2 suppresses CDX2 expression and inhibits intestinal neoplastic epithelial cell differentiation. Oncotarget. 2015; 6:30993-1006. https://doi.org/10.18632/oncotarget.5206.

18. Du X, Dong Y, Shi H, Li J, Kong S, Shi D, Sun LV, Xu T, Deng K, Tao W. Mst1 and mst2 are essential regulators of trophoblast differentiation and placenta morphogenesis. PLoS One. 2014; 9:e90701. https://doi.org/10.1371/journal. pone.0090701.

19. Cowden Dahl KD, Fryer BH, Mack FA, Compernolle V, Maltepe E, Adelman DM, Carmeliet P, Simon MC. Hypoxia-inducible factors 1alpha and 2alpha regulate trophoblast differentiation. Mol Cell Biol. 2005; 25:1047991. https://doi.org/10.1128/MCB.25.23.10479-10491.2005.

20. Renaud SJ, Chakraborty D, Mason CW, Rumi MA, Vivian JL, Soares MJ. OVO-like 1 regulates progenitor cell fate in human trophoblast development. Proc Natl Acad Sci U S A. 2015; 112:E6175-84. https://doi.org/10.1073/ pnas. 1507397112 .

21. Dessein AF, Stechly L, Jonckheere N, Dumont P, Monte D, Leteurtre E, Truant S, Pruvot FR, Figeac M, Hebbar M, Lecellier CH, Lesuffleur T, Dessein R, et al. Autocrine induction of invasive and metastatic phenotypes by the MIF-CXCR4 axis in drug-resistant human colon cancer cells. Cancer Res. 2010; 70:4644-54. https://doi. org/10.1158/0008-5472.CAN-09-3828.

22. Birkenkamp-Demtroder K, Maghnouj A, Mansilla F, Thorsen K, Andersen CL, Oster B, Hahn S, Orntoft TF. Repression of KIAA1199 attenuates Wnt-signalling and decreases the proliferation of colon cancer cells. Br
J Cancer. 2011; 105:552-61. https://doi.org/10.1038/ bjc.2011.268.

23. Shang Y, Chen H, Ye J, Wei X, Liu S, Wang R. HIF-1 $\alpha$ / ASCL2/miR-200b regulatory feedback circuit modulated the epithelial-mesenchymal transition (EMT) in colorectal cancer cells. Exp Cell Res. 2017; 360:243-56. https://doi. org/10.1016/j.yexcr.2017.09.014.

24. Harvey KF, Zhang X, Thomas DM. The Hippo pathway and human cancer. Nat Rev Cancer. 2013; 13:246-57. https:// doi.org/10.1038/nrc3458.

25. Moya IM, Halder G. Discovering the Hippo pathway protein-protein interactome. Cell Res. 2014; 24:137-8. https://doi.org/10.1038/cr.2014.6.

26. Johnson R, Halder G. The two faces of Hippo: targeting the Hippo pathway for regenerative medicine and cancer treatment. Nat Rev Drug Discov. 2014; 13:63-79. https:// doi.org/10.1038/nrd4161.

27. Chan EH, Nousiainen M, Chalamalasetty RB, Schafer A, Nigg EA, Sillje HH. The Ste20-like kinase Mst2 activates the human large tumor suppressor kinase Lats1. Oncogene. 2005; 24:2076-86. https://doi.org/10.1038/sj.onc.1208445.

28. Praskova M, Xia F, Avruch J. MOBKL1A/MOBKL1B phosphorylation by MST1 and MST2 inhibits cell proliferation. Curr Biol. 2008; 18:311-21. https://doi. org/10.1016/j.cub.2008.02.006.

29. Lei QY, Zhang H, Zhao B, Zha ZY, Bai F, Pei XH, Zhao $\mathrm{S}$, Xiong Y, Guan KL. TAZ promotes cell proliferation and epithelial-mesenchymal transition and is inhibited by the Hippo pathway. Mol Cell Biol. 2008; 28:2426-36. https:// doi.org/10.1128/MCB.01874-07.

30. Wu S, Liu Y, Zheng Y, Dong J, Pan D. The TEAD/TEF family protein scalloped mediates transcriptional output of the Hippo growth-regulatory pathway. Dev Cell. 2008; 14:388-98. https://doi.org/10.1016/j.devcel.2008.01.007.

31. Zhao B, Ye X, Yu J, Li L, Li W, Li S, Yu J, Lin JD, Wang CY, Chinnaiyan AM, Lai ZC, Guan KL. TEAD mediates YAPdependent gene induction and growth control. Genes Dev. 2008; 22:1962-71. https://doi.org/10.1101/gad.1664408.

32. Vassilev A, Kaneko KJ, Shu H, Zhao Y, DePamphilis ML. TEAD/TEF transcription factors utilize the activation domain of YAP65, a Src/Yes-associated protein localized in the cytoplasm. Genes Dev. 2001; 15:1229-41. https://doi. org/10.1101/gad.888601.

33. Varelas X, Miller BW, Sopko R, Song S, Gregorieff A, Fellouse FA, Sakuma R, Pawson T, Hunziker W, McNeill H, Wrana JL, Attisano L. The Hippo pathway regulates Wnt/beta-catenin signaling. Dev Cell. 2010; 18:579-91. https://doi.org/10.1016/j.devcel.2010.03.007.

34. Rosenbluh J, Nijhawan D, Cox AG, Li X, Neal JT, Schafer EJ, Zack TI, Wang X, Tsherniak A, Schinzel AC, Shao DD, Schumacher SE, Weir BA, et al. $\beta$-Catenindriven cancers require a YAP1 transcriptional complex for survival and tumorigenesis. Cell. 2012; 151:1457-73. https://doi.org/10.1016/j.cell.2012.11.026. 
35. Bernascone I, Martin-Belmonte F. Crossroads of Wnt and Hippo in epithelial tissues. Trends Cell Biol. 2013; 23:380 9. https://doi.org/10.1016/j.tcb.2013.03.007.

36. Imajo M, Miyatake K, Iimura A, Miyamoto A, Nishida E. A molecular mechanism that links Hippo signalling to the inhibition of Wnt/beta-catenin signalling. EMBO J. 2012; 31:1109-22. https://doi.org/10.1038/emboj.2011.487.

37. Azzolin L, Zanconato F, Bresolin S, Forcato M, Basso G, Bicciato S, Cordenonsi M, Piccolo S. Role of TAZ as mediator of Wnt signaling. Cell. 2012; 151:1443-56. https://doi.org/10.1016/j.cell.2012.11.027.

38. Gregorieff A, Liu Y, Inanlou MR, Khomchuk Y, Wrana JL. YAP-dependent reprogramming of Lgr5(+) stem cells drives intestinal regeneration and cancer. Nature. 2015; 526:715-8. https://doi.org/10.1038/nature15382.

39. Chen WC, Lin HH, Tang MJ. Matrix-stiffness-regulated inverse expression of kruppel-like factor 5 and kruppellike factor 4 in the pathogenesis of renal fibrosis. Am J Pathol. 2015; 185:2468-81. https://doi.org/10.1016/j. ajpath.2015.05.019.

40. Zhi X, Zhao D, Zhou Z, Liu R, Chen C. YAP promotes breast cell proliferation and survival partially through stabilizing the KLF5 transcription factor. Am J Pathol. 2012; 180:2452-61. https://doi.org/10.1016/j.ajpath.2012.02.025.

41. Gao Y, Wu K, Chen Y, Zhou J, Du C, Shi Q, Xu S, Jia J, Tang X, Li F, Hui K, He D, Guo P. Beyond proliferation: KLF5 promotes angiogenesis of bladder cancer through directly regulating VEGFA transcription. Oncotarget. 2015; 6:43791-805. https://doi.org/10.18632/oncotarget.6101.

42. Lu L, Li Y, Kim SM, Bossuyt W, Liu P, Qiu Q, Wang Y, Halder G, Finegold MJ, Lee JS, Johnson RL. Hippo signaling is a potent in vivo growth and tumor suppressor pathway in the mammalian liver. Proc Natl Acad Sci U S A. 2010; 107:1437-42. https://doi.org/10.1073/ pnas.0911427107.

43. Camargo FD, Gokhale S, Johnnidis JB, Fu D, Bell GW, Jaenisch R, Brummelkamp TR. YAP1 increases organ size and expands undifferentiated progenitor cells. Curr Biol. 2007; 17:2054-60. https://doi.org/10.1016/j. cub.2007.10.039.

44. St John MA, Tao W, Fei X, Fukumoto R, Carcangiu ML, Brownstein DG, Parlow AF, McGrath J, Xu T. Mice deficient of Lats1 develop soft-tissue sarcomas, ovarian tumours and pituitary dysfunction. Nat Genet. 1999; 21:182-6. https://doi.org/10.1038/5965.

45. Overholtzer M, Zhang J, Smolen GA, Muir B, Li W, Sgroi DC, Deng CX, Brugge JS, Haber DA. Transforming properties of YAP, a candidate oncogene on the chromosome 11q22 amplicon. Proc Natl Acad Sci U S A. 2006; 103:12405-10. https://doi.org/10.1073/pnas.0605579103.

46. Muramatsu T, Imoto I, Matsui T, Kozaki K, Haruki S, Sudol M, Shimada Y, Tsuda H, Kawano T, Inazawa J. YAP is a candidate oncogene for esophageal squamous cell carcinoma. Carcinogenesis. 2011; 32:389-98. https://doi. org/10.1093/carcin/bgq254.

47. Zanconato F, Cordenonsi M, Piccolo S. YAP/TAZ at the roots of cancer. Cancer Cell. 2016; 29:783-803. https://doi. org/10.1016/j.ccell.2016.05.005.

48. Cordenonsi M, Zanconato F, Azzolin L, Forcato M, Rosato A, Frasson C, Inui M, Montagner M, Parenti AR, Poletti A, Daidone MG, Dupont S, Basso G, et al. The Hippo transducer TAZ confers cancer stem cell-related traits on breast cancer cells. Cell. 2011; 147:759-72. https://doi. org/10.1016/j.cell.2011.09.048.

49. Chen CL, Tsukamoto H, Liu JC, Kashiwabara C, Feldman D, Sher L, Dooley S, French SW, Mishra L, Petrovic L, Jeong JH, Machida K. Reciprocal regulation by TLR4 and TGF-beta in tumor-initiating stem-like cells. J Clin Invest. 2013; 123:2832-49. https://doi.org/10.1172/JCI65859.

50. Kwon OH, Park JL, Baek SJ, Noh SM, Song KS, Kim SY, Kim YS. Aberrant upregulation of ASCL2 by promoter demethylation promotes the growth and resistance to 5-fluorouracil of gastric cancer cells. Cancer Sci. 2013; 104:391-7. https://doi.org/10.1111/cas.12076.

51. Hu XG, Chen L, Wang QL, Zhao XL, Tan J, Cui YH, Liu XD, Zhang X, Bian XW. Elevated expression of ASCL2 is an independent prognostic indicator in lung squamous cell carcinoma. J Clin Pathol. 2016; 69:313-8. https://doi. org/10.1136/jclinpath-2015-203025.

52. Katoh M, Katoh M. Molecular genetics and targeted therapy of Wnt-related human diseases (review). Int J Mol Med. 2017; 40:587-606. https://doi.org/10.3892/ ijmm.2017.3071.

53. Song S, Ajani JA, Honjo S, Maru DM, Chen Q, Scott AW, Heallen TR, Xiao L, Hofstetter WL, Weston B, Lee JH, Wadhwa R, Sudo K, et al. Hippo coactivator YAP1 upregulates SOX9 and endows esophageal cancer cells with stem-like properties. Cancer Res. 2014; 74:4170-82. https:// doi.org/10.1158/0008-5472.CAN-13-3569.

54. Yu FX, Zhao B, Guan KL. Hippo pathway in organ size control, tissue homeostasis, and cancer. Cell. 2015; 163:811-28. https://doi.org/10.1016/j.cell.2015.10.044.

55. Komuro A, Nagai M, Navin NE, Sudol M. Ww domaincontaining protein YAP associates with ErbB-4 and acts as a co-transcriptional activator for the carboxyl-terminal fragment of ErbB-4 that translocates to the nucleus. J Biol Chem. 2003; 278:33334 41. https://doi.org/10.1074/jbc.M305597200.

56. Jia L, Zhou Z, Liang H, Wu J, Shi P, Li F, Wang Z, Wang C, Chen W, Zhang H, Wang Y, Liu R, Feng J, et al. KLF5 promotes breast cancer proliferation, migration and invasion in part by upregulating the transcription of TNFAIP2. Oncogene. 2016; 35:2040-51. https://doi.org/10.1038/ onc.2015.263.

57. Dardousis K, Voolstra C, Roengvoraphoj M, Sekandarzad A, Mesghenna S, Winkler J, Ko Y, Hescheler J, Sachinidis A. Identification of differentially expressed genes involved in the formation of multicellular tumor spheroids by HT-29 
colon carcinoma cells. Mol Ther. 2007; 15:94-102. https:// doi.org/10.1038/sj.mt.6300003.

58. Tian Y, Pan Q, Shang Y, Zhu R, Ye J, Liu Y, Zhong X, Li S, He Y, Chen L, Zhao J, Chen W, Peng Z, et al. Microrna-200 (miR-200) cluster regulation by achaete scute-like 2 (ASCL2): impact on the epithelial-mesenchymal transition in colon cancer cells. J Biol Chem. 2014; 289:36101-15. https://doi.org/10.1074/jbc.M114.598383.
59. Pan Q, Meng L, Ye J, Wei X, Shang Y, Tian Y, He Y, Peng Z, Chen L, Chen W, Bian X, Wang R. Transcriptional repression of mir-200 family members by nanog in colon cancer cells induces epithelial-mesenchymal transition (EMT). Cancer Lett. 2017; 392:26-38. https://doi. org/10.1016/j.canlet.2017.01.039. 